Article

\title{
The Presence of Toxic and Non-Toxic Cyanobacteria in the Sediments of the Limpopo River Basin: Implications for Human Health
}

\author{
Murendeni Magonono ${ }^{1}$, Paul Johan Oberholster ${ }^{2}$, Addmore Shonhai $^{3}$, Stanley Makumire ${ }^{3}$ and \\ Jabulani Ray Gumbo ${ }^{1, *}$ (D) \\ 1 Department of Hydrology and Water Resources, School of Environmental Sciences, University of Venda, \\ Thohoyandou 0950, South Africa; murendy22@gmail.com \\ 2 Council for Scientific and Industrial Research, Natural Resources and the Environment, Stellenbosch 7600, \\ South Africa; poberholster@csir.co.za \\ 3 Department of Biochemistry, School of Mathematical and Natural Sciences, University of Venda, \\ Thohoyandou 0950, South Africa; addmore.shonhai@univen.ac.za (A.S.); stanmakster@gmail.com (S.M.) \\ * Correspondence: jabulani.gumbo@univen.ac.za; Tel.: +27-15-962-8563
}

Received: 10 May 2018; Accepted: 21 June 2018; Published: 3 July 2018

\begin{abstract}
The presence of harmful algal blooms (HABs) and cyanotoxins in drinking water sources poses a great threat to human health. The current study employed molecular techniques to determine the occurrence of non-toxic and toxic cyanobacteria species in the Limpopo River basin based on the phylogenetic analysis of the 16S rRNA gene. Bottom sediment samples were collected from selected rivers: Limpopo, Crocodile, Mokolo, Mogalakwena, Nzhelele, Lephalale, Sand Rivers (South Africa); Notwane (Botswana); and Shashe River and Mzingwane River (Zimbabwe). A physical-chemical analysis of the bottom sediments showed the availability of nutrients, nitrates and phosphates, in excess of $0.5 \mathrm{mg} / \mathrm{L}$, in most of the river sediments, while alkalinity, $\mathrm{pH}$ and salinity were in excess of $500 \mathrm{mg} / \mathrm{L}$. The FlowCam showed the dominant cyanobacteria species that were identified from the sediment samples, and these were the Microcystis species, followed by Raphidiopsis raciborskii, Phormidium and Planktothrix species. The latter species were also confirmed by molecular techniques. Nevertheless, two samples showed an amplification of the cylindrospermopsin polyketide synthetase gene (S3 and S9), while the other two samples showed an amplification for the microcystin/nodularin synthetase genes (S8 and S13). Thus, these findings may imply the presence of toxic cyanobacteria species in the studied river sediments. The presence of cyanobacteria may be hazardous to humans because rural communities and farmers abstract water from the Limpopo river catchment for human consumption, livestock and wildlife watering and irrigation.
\end{abstract}

Keywords: cyanobacteria; cyanotoxins; nutrient enrichment; akinetes; harmful algal blooms; PCR; phylogenetic analyses

Key Contribution: Presence of viable cyanobacteria akinetes and cysts in river sediments; a source of inoculum of cyanobacteria growth in the Limpopo river basin. Some of the cyanobacteria species are toxic.

\section{Introduction}

Toxic and non-toxic cyanobacteria species are on the increase in most parts of the world, including in South Africa. The emergence and resurgence of harmful algal blooms (HABS) is due to eutrophication. The toxic cyanobacteria are known to carry genes that produce cyanotoxins which are lethal to humans. However, the toxic and non-toxic cyanobacteria species merely differ in the 
mcy gene content, which is the peptide synthetase producing microcystin [1]. This may explain the observation of non-detectable microsystin toxin despite the presence of mcy gene [2]. A study by Frazao et al. [3] used the PCR method to determine molecular analysis of genes involved in the production of known cyanotoxins, microcystins, nodularins and cylindrospermopsin. The toxic strains of the cyanobacteria genera, Leptolyngbya, Oscillatoria, Microcystis, Planktothrix and Anabaena are known to have in common the mcy $(A-E, G, J)$ genes that are involved in the biosynthesis of microcystin $[1,3]$. The nodularin cyanotoxin is linked to the $n d a$ synthetase gene, a polyketide synthase (PKS) and nonribosomal peptide synthetase (NRPS) and biosynthesized by Nodularia spumigena NSOR10 cyanobacteria [4]. The review studies carried out by Pearson et al. [4] and Sinha [5] showed that cyanotoxin cylindrospermopsin is linked to the genes aoa or cyr $(A-O)$ and is now known to be biosynthesized by a number of cyanobacteria genera, such as Cylindrospermopsis and Umezakia natans in Japan; Aphanizomenon ovalisporum in Israel, Australia, USA and Spain; Anabaena bergii in Australia; Raphidiopsis raciborskii in Thailand, China and Australia; Raphidiopsis curvata in China; Aphanizomenon flos-aquae in Germany; Anabaena lapponica in Finland; Lyngbya wollei in Australia; Aphanizomenon gracile in Germany; Oscillatoria sp. in the USA Aphanizomenon sp. in Germany; and Raphidiopsis mediterranea, Dolichospermum mendotae and Chrysosporum ovalisporum in Turkey.

The emergence of toxic cyanobacteria species during a bloom period is linked to environmental factors such as light, nutrient enrichment or nutrient depletion, and the presence or non-presence of predators [4]. Eutrophication, a build-up of organic matter produced by phototrophs, such as cyanobacteria [6,7], is often seen as algal blooms and driven by inputs of nitrogen and phosphorus. Cyanobacteria blooms are a major concern worldwide due to the production of cyanotoxins which are harmful to humans [8]. Cyanobacteria tend to proliferate during the summer when concentrations of total phosphorus fall to 100-1000 $\mu \mathrm{g} / \mathrm{L}$ [9]. A variety of hypotheses explain why cyanobacteria blooms are becoming increasingly prevalent [10-12]. The most common hypotheses focus on nutrient conditions [10,11,13-17] and nutrient cycling [18] within a water body, as well as aspects of cyanobacteria cell physiology, such as their ability to migrate vertically within the water column, fix atmospheric nitrogen and to produce cyanotoxins [19-22].

Cyanobacterial blooms are often associated with eutrophic conditions [23-25]. Various studies have documented the relationship between nitrogen and phosphorus concentrations, speciation and stoichiometry, and cyanobacteria occurrence $[10,13]$. A recent study reported that Microcystis growth response increases in relation to nitrogen over phosphorus [26]. The same study [26] also reported that the growth response of toxic Microcystis to nitrogen was greater than non-toxic strains. Some species of cyanobacteria are known for their ability to fix nitrogen and thus giving them high chances of producing cyanotoxins [27]. Other studies have shown that microcystin toxicity is also influenced by changes in $\mathrm{pH}$, temperature and light intensity [28-30]. A study conducted by Beversdorf et al., [27] indicated that some of the non-nitrogen fixing cyanobacteria may produce toxins because of nitrogen stress events.

However, a review of the available literature shows that there is limited information on the occurrence of toxic and non-toxic cyanobacteria species in relationship with river basin sediments on the African continent [31]. Thus, the main objectives of the study were to: (1) assess the physical-chemical characteristics of river sediments and how these contribute to the resurgence and growth of cyanobacteria species should ideal river flow conditions return; (2) use the FlowCam and molecular techniques to identify toxic and non-toxic cyanobacteria genes in the river sediments; and (3) to use the $16 \mathrm{~S}$ rRNA in identifying the cyanobacteria species and explore relationships among the cyanobacteria species in the river sediments. 


\section{Results}

\subsection{The Physical-Chemical Characteristics of the River Sediments}

The physical characteristics of the river sediments drawn from the different tributaries of the Limpopo River basin and the Limpopo River itself showed considerable variation (Figure 1). The electrical conductivity (EC) and total dissolved solids (TDS) values in the river sediments ranged between 21.2 and $1269 \mu \mathrm{S} \mathrm{cm}{ }^{-1}$ throughout the sampling sites. The $\mathrm{pH}$ values were between 6.4 and 8.5 , while the total phosphorus concentration values in the river sediments ranged from $0.5 \mathrm{mg} / \mathrm{L}$ to $6.3 \mathrm{mg} / \mathrm{L}$ (Figure 2). The highest total phosphorus value was recorded for the sediments from the Nzhelele River (S12) near the Mphephu Resort and downstream of the Siloam oxidation ponds. The second highest phosphorus concentrations were measured at the Shashe River (S13), with the total phosphorus measuring $1.2 \pm 0.5 \mathrm{mg} / \mathrm{L}$ at sample point $\mathrm{S} 18$.

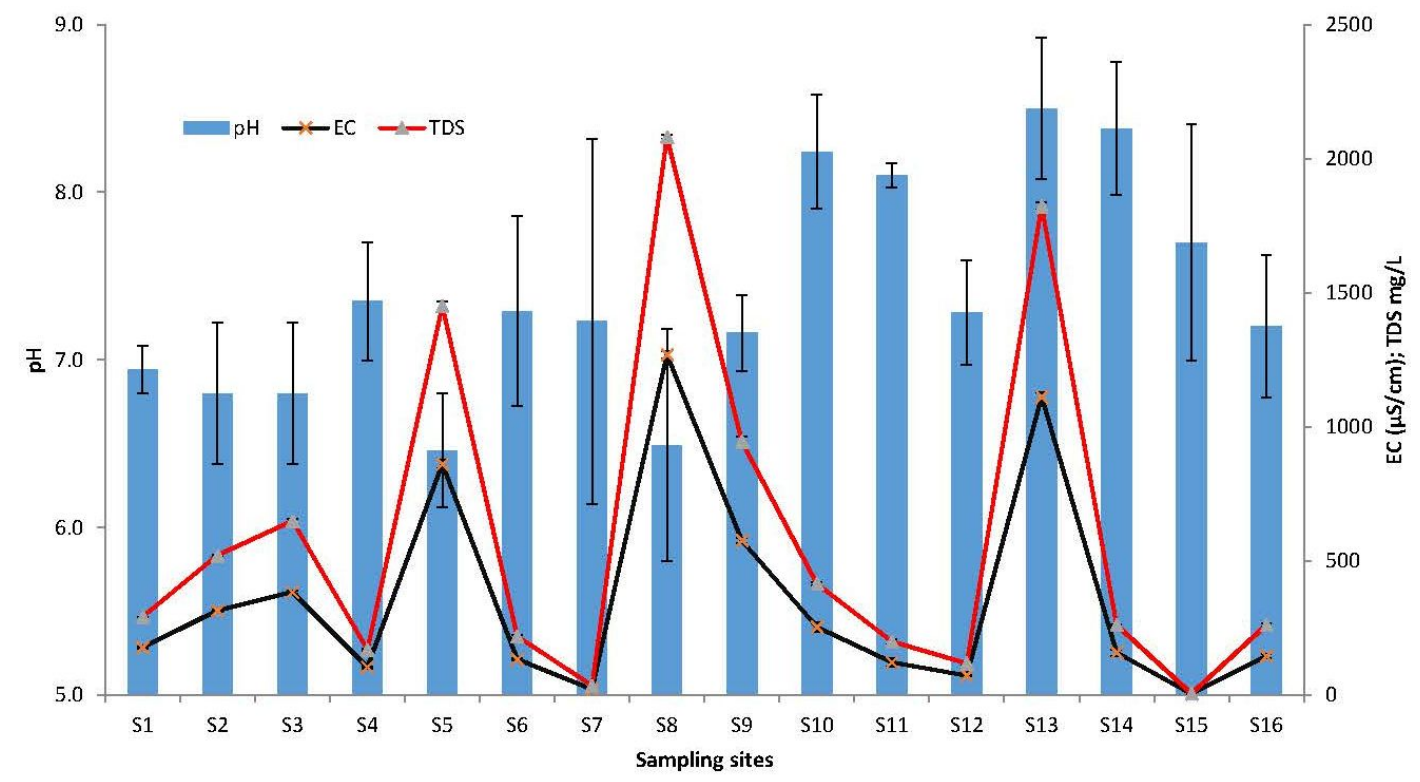

Figure 1. Average values of the physical characteristics of the river sediments of the 18 sampling sites. Whiskers reflect standard error. EC: electrical conductivity; TDS: total dissolved solids.

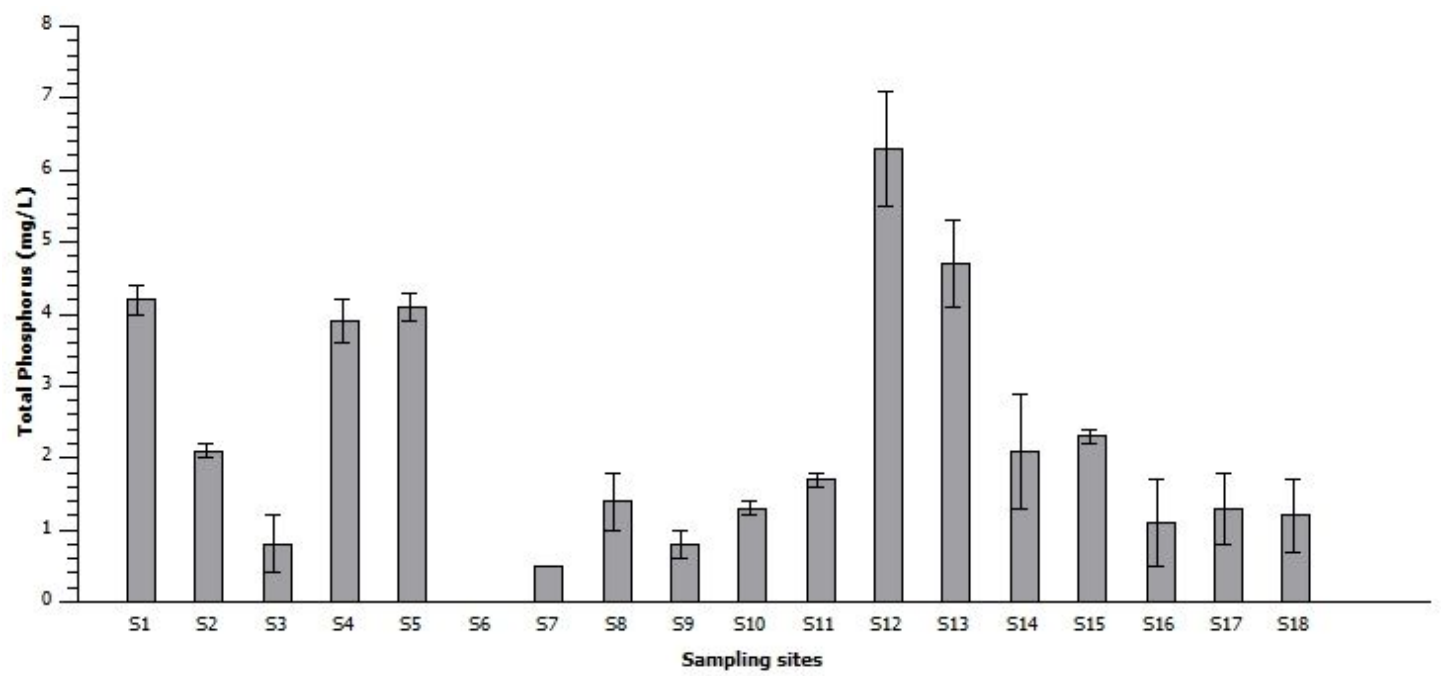

Figure 2. Average values of total phosphorus in the river sediments of the 18 sampling sites. Whiskers reflect standard error. 
Finally, the nitrogen concentration values in the river sediments ranged from $1.5 \mathrm{mg} / \mathrm{L}$ to $6.5 \mathrm{mg} / \mathrm{L}$ (Figure 3). The highest concentrations were recorded for the sample from the Nzhelele River (S12) near the Mphephu Resort and downstream of the Siloam Hospital oxidation ponds, while the total nitrogen at site S18 was $6.25 \mathrm{mg} / \mathrm{L}$.

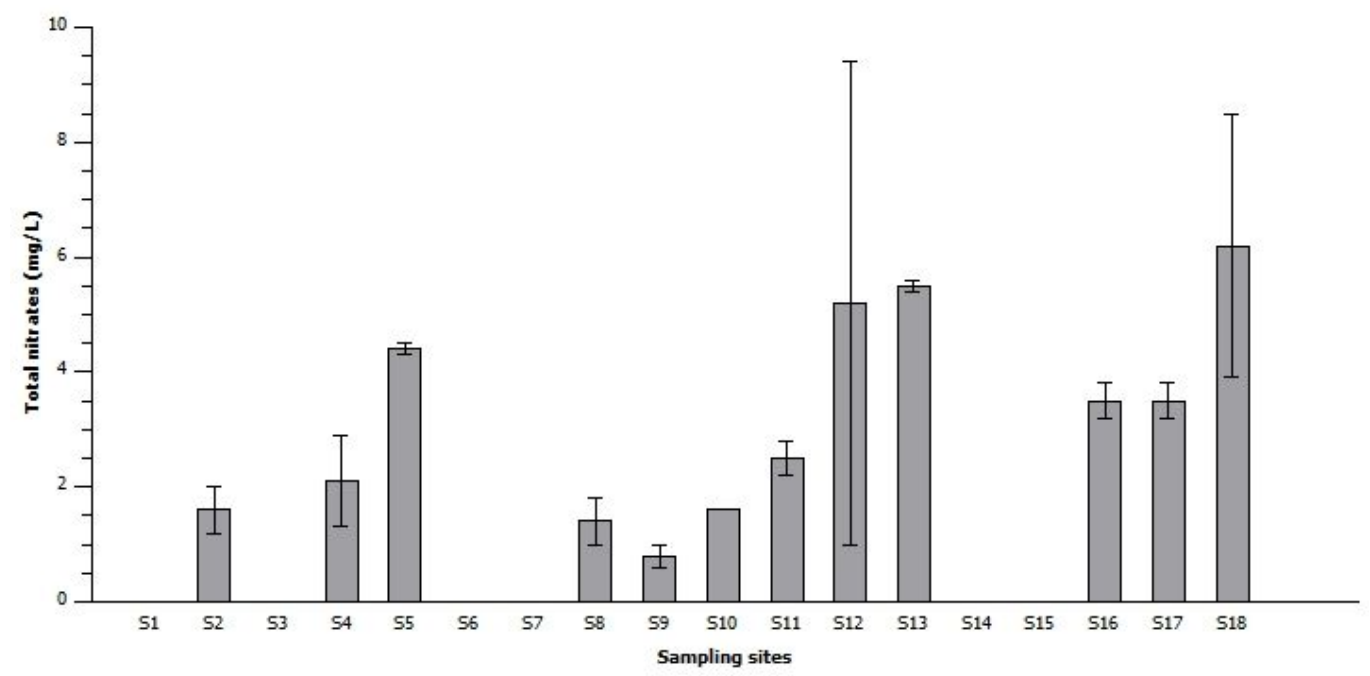

Figure 3. Average values of total nitrogen in the river sediments. Whiskers reflect standard error.

\subsection{The Presence of Cyanobacteria in the River Sediments}

Table 1 shows the presence of toxic and non-toxic cyanobacteria species that were detected in the Limpopo River basin. The dominant cyanobacteria observed is the filamentous Leptolyngbya species, followed by the Synechocystis species (non-toxic and toxic strains), toxigenic Microcystis species, and toxigenic Raphidiopsis raciborskii species. The FlowCam showed the presence of the different cyanobacteria species in the Limpopo River basin, as shown in Table 1 and Figure 4. The dominant cyanobacteria species identified from the samples were the Microcystis species, followed by the Raphidiopsis raciborskii, Calothrix, Phormidium and Planktothrix species. Finally, no cyanobacteria species were detected in the Mokolo River (S7).

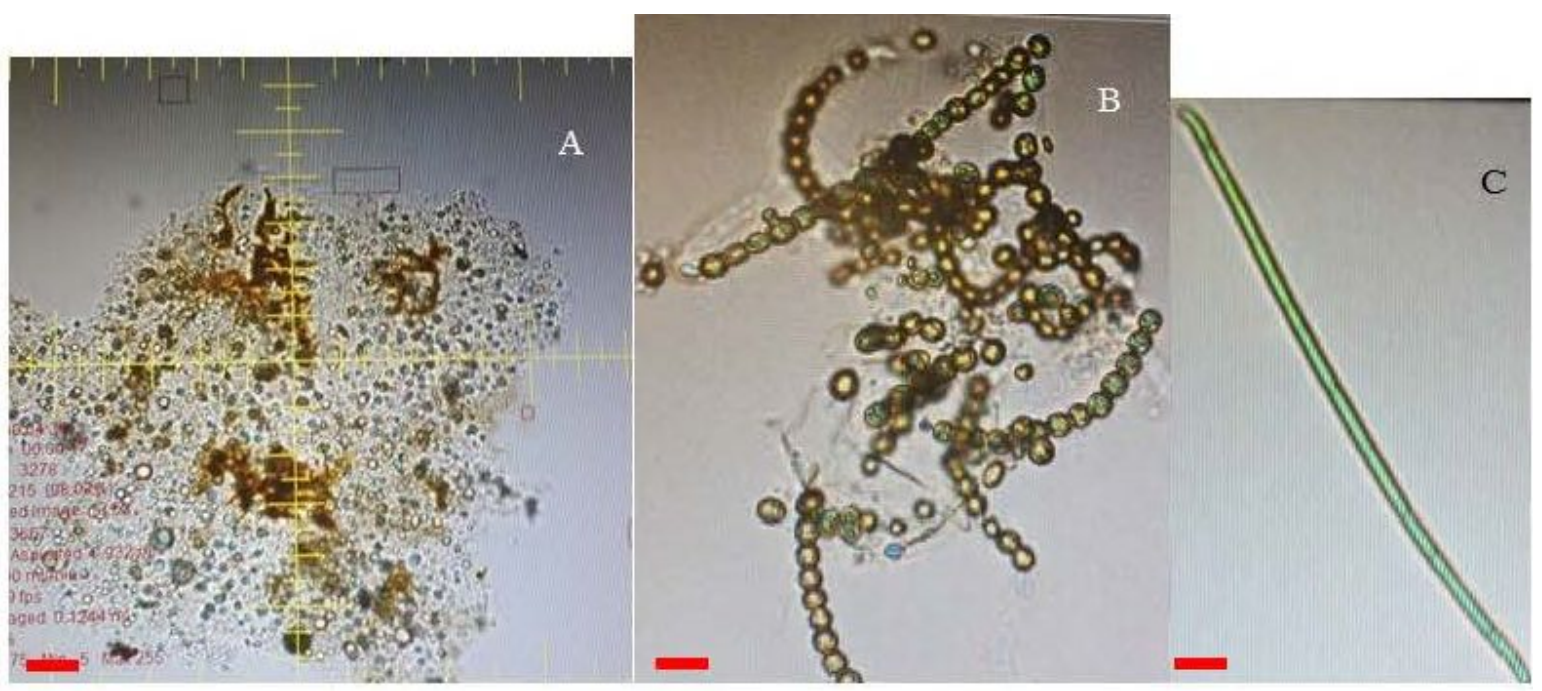

Figure 4. The (A) Microcystis, (B) Anabaena and (C) Oscillatoria species in the river sediments. Red scale bar $=20 \mu \mathrm{m}$. 
Table 1. Summary of toxic and non-toxic cyanobacteria species in the Limpopo river basin.

\begin{tabular}{|c|c|c|c|c|c|c|c|c|c|c|c|c|c|c|c|c|c|c|}
\hline $\begin{array}{c}\text { Cyanobacteria } \\
\text { Species/Sample Sites }\end{array}$ & S1 & $\mathrm{S} 2$ & S3 & S4 & S5 & S6 & S7 & S8 & S9 & S10 & S11 & $\mathrm{S} 12$ & S13 & S14 & S15 & S16 & S17 & S18 \\
\hline Aphanizomenon sp. & & & $+*$ & & & & & & & & & & & & & & & \\
\hline Raphidiopsis curvata & & & $+*$ & & & & & & & & & & & & & & & \\
\hline Microcystis aeruginosa & + & & + & + & + & & & $++*$ & & + & + & + & $++*$ & + & + & & + & \\
\hline Microcystis panniformis & & & & & & & & $+^{*}$ & & & & & & & & & & \\
\hline Synechocystis PCC 6803 & & & $+^{*}$ & & & & + & & + & & & & & & & & & \\
\hline Cylindrospermopsis sp. & & & $+^{*}$ & & & & & & $+^{*}$ & & & & & & & & & \\
\hline Lyngbya sp. & + & & & & & & & & & & & & & & & & & \\
\hline Leptolyngbya sp. & & + & & & & & & & & & & & & & & + & & \\
\hline Leptolyngbya boryana & & & & & & & & + & & & & & & + & & & & \\
\hline Calothrix sp. & & + & & & & & & + & $++^{*}$ & & & & + & + & & & & \\
\hline Oscillatoria sp. & & + & + & & & & & & $++^{*}$ & & & & & & & & & \\
\hline Phormidium sp. & & + & & & + & & & & & + & & & & & + & & & \\
\hline Phormidium uncinatum & & & + & & & & & & & & & & & & & & & \\
\hline Nostoc sp. & & & $+^{*}$ & & + & & & & & & & & $+^{*}$ & & & & & \\
\hline Anabaena circinalis & & & & & + & & & & & & & & & & & & & \\
\hline Anabaena oscillarioides & & & & & + & & & & & & & & & & & & & \\
\hline Chroococcus & & & & & & + & & & & & & & & & & & & \\
\hline Anabaechopsis circularis & & & & & & + & & & & & & & & & & & & \\
\hline Spirulina laxissima SAG 256.80 & & & & & & & & & & + & & & & & & & & \\
\hline Planktothrix rubescens & & & & & & & & $+^{*}$ & & & & & $+*$ & & & & & + \\
\hline Alkalinema pantanalense & & & & & & & & & & & & & & & & & & + \\
\hline Gloeocapsa sp. & & & & & & & & & $+*$ & & + & & & & & & & \\
\hline Arthrospira sp. str PCC 8005 & & & $+{ }^{*}$ & & & & & & & & & & & & & & & \\
\hline
\end{tabular}




\subsection{PCR Analysis of the $16 S$ rRNA Gene}

Multiple fragments were obtained for each sample by sequencing with both forward and reverse primers, and these samples were edited and assembled using the Staden package [32]. All assembled sequences were aligned in BioEdit v7.0.9 [33]. However, the sample collected from the Limpopo River (S1) was not shown in Figure 5, since it was used as the test sample. It was also noted that the amplified fragment from the test sample only produced $100 \mathrm{bp}$, while around $650 \mathrm{bp}$ was expected. Other samples, such as the samples Limpopo River (S15), Limpopo River (S17) and Musina borehole abstraction point (S16), did amplify, but failed to assemble in the Staden package [32]. The assembled sequences were run on the BLAST algorithm [34] to identify closely similar sequences already deposited in GenBank via NCBI, and the outcomes are shown in Table 2.

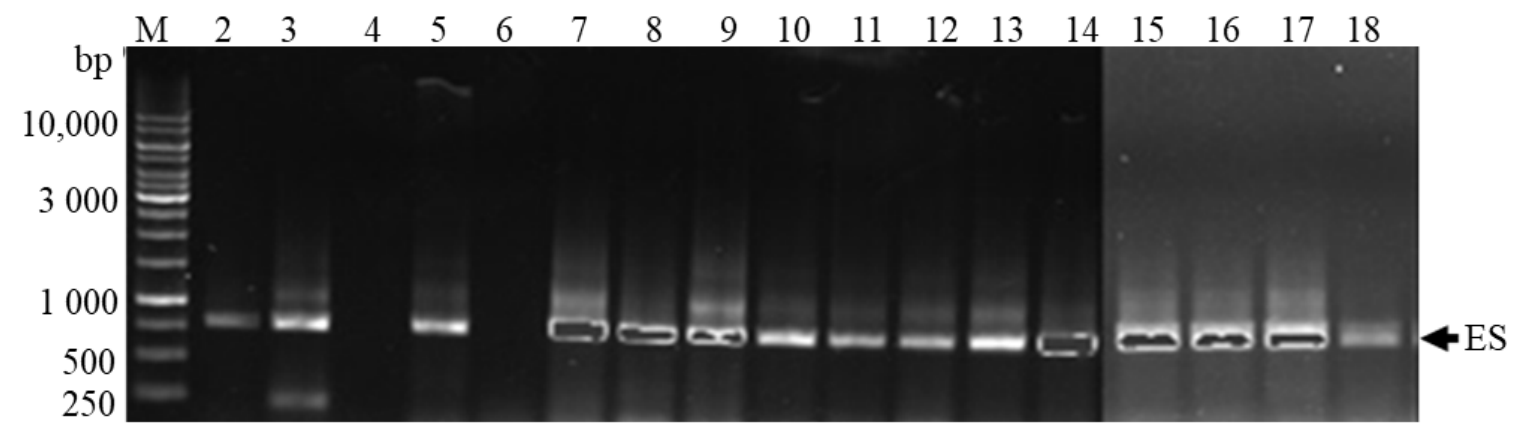

Figure 5. PCR amplification using $27 \mathrm{~F}$ and $740 \mathrm{R}$ primer pair for $16 \mathrm{~S}$ rRNA gene. ES (estimated fragments); M (Standard Marker), 2-18 Sample numbers. Lane 2 = Notwane River; 3 = Sand River upstream; 4 = Mogalakwena River; 5 = Mawoni River; 6 = Lephalale River; 7 = Mokolo River; 8 = Crocodile River downstream of Hartbeespoort Dam; 9 = Nzhelele River downstream; 10 = Sand River downstream; 11 = Crocodile River downstream (near the bridge on road D1235); 12 = Nzhelele River upstream; 13 = Mzingwane River; 14 = Shashe River; 15 = Limpopo River (next to Thuli Coalmine); 16 = Limpopo River (abstraction point at $0.0 \mathrm{~m}$ ); 17 = Limpopo River (abstraction point at $1.0 \mathrm{~m}$ ); 18 = Limpopo River (abstraction point at $1.68 \mathrm{~m}$ ).

Table 2. Results from the BLAST search showing the similarity between the GenBank sequences and the sample sequences from this study. The families of each species are shown in a separate column.

\begin{tabular}{ccccc}
\hline Samples & Similarity $\%$ & Species Similar to & Family & Accession No \\
\hline S2 & 93 & Uncultured Leptolyngbya sp. Clone & Leptolyngbyaceae & KM108695.1 \\
S3 & 94 & Synechocystis PCC 6803 & Oscillatoriophycideae & CP012832.1 \\
S5 & 97 & Anabaena oscillarioides & Nostocaceae & AJ630428.1 \\
S7 & 99 & Synechocystis sp. PCC 6803 & Oscillatoriophycideae & CP012832.1 \\
S8 & 99 & Leptolyngbya boryana & Leptolyngbyaceae & AP014642.1 \\
S9 & 97 & Synechocystis PCC 6803 & Oscillatoriophycideae & CP012832.1 \\
S9 & 100 & Cylindrospermopsis raciborskii & Oscillatoriophycideae & KJ139743.1 \\
S9 & 100 & CHAB3438 & Nostocaceae & GQ385961.1 \\
S9 & 100 & Aphanizomenon sp. & Nostocaceae & KJ139745.1 \\
S10 & 96 & Raphidiopsis curvata & Spirulinaceae & DQ393278.1 \\
S11 & 87 & Spirulina laxissima SAG 256.80 & - & AM159315.1 \\
S12 & 83 & Uncultured Cyanobacterium clone & - & HQ189039.1 \\
S13 & 90 & Uncultured Cyanobacterium clone & J & A 041703.1 \\
S14 & 98 & Leptolyngbya boryana & Leptolyngbyaceae & AP014642.1 \\
S16 & 83 & Leptolyngbya & Leptolyngbyaceae & KJ654311.1 \\
S18 & 96 & Alkalinema pantanalense & Pseudanabaenaceae & KF246497.2 \\
\hline
\end{tabular}

It must be understood from the BLAST algorithm [34] that more than $98 \%$ similarity obtained matches the sample to the correct species, more than $90 \%$ similarity obtained matches the sample to the correct genus, while more than $80 \%$ similarity obtained matches the sample at the Family level. 
The PCR products that were separated by gel electrophoresis are shown in Figure 5. The presence of the different bands indicated a positive amplification, whereas a blank sample indicated a negative amplification. The blank samples where repeated several times and failed to amplify. Almost all of the samples showed positive amplification, which confirmed the presence of cyanobacterial DNA in the samples. The two samples which showed no amplification were drawn from the Mogalakwena (S4) and Lephalale Rivers (S6). The BLAST algorithm [34] showed that more than 98\% similarity obtained matches the sample to the correct species, more than $90 \%$ similarity obtained matches the sample to the correct genus, while more than $80 \%$ similarity obtained matches the sample to the correct family.

BLAST data from the samples drawn from the Mokolo River (S7), Crocodile River downstream of Hartbeespoort Dam (S8) and the Shashe River (S14) did not identify the cyanobacteria up to the species level. However, the cyanobacteria from the samples drawn from the Notwane River (S2), Sand River upstream (S3), Mawoni River (S5), Nzhelele River downstream (S9), Sand river downstream and the Limpopo River (S18) (abstraction point at $1.68 \mathrm{~m}$ ) were identified up to genus level. Lastly, the cyanobacteria from the sampled Limpopo River (S16) (abstraction point at $0.0 \mathrm{~m}$ ) was identified up to the family level. Furthermore, the samples from Crocodile River downstream (S11) (near bridge on road D1235), Nzhelele River upstream (S12) and Mzingwane River (S13) showed similarities and there were no families that could be detected for these samples.

\subsection{Detection of Genes Involved in Toxin Production}

The detection of cyanotoxins was done through detecting genes for the proteins that make toxins. This was achieved with PCR by amplification of microcystin/nodularin synthetase using the HEP primer pairs and cylindrospermopsin polyketide synthetase genes using a PKS primer pair. It must be noted that the detection of the genes involved in the biosynthesis of toxins does not confirm the production of the toxins in the field. The $m c y A-C$ primer pair and M13 and M14 primer pair were also used to determine the presence of the genes that contain the proteins for toxins production. However, the genes were not detected, as there was no amplification in most of the samples of any of the genes associated with the proteins that produce toxins. Nevertheless, a few samples, such as the Sand River (S3) upstream and Nzhelele River (S9) downstream (Figure 6), showed the amplification of the cylindrospermopsin polyketide synthetase gene. This confirmed the presences of cyanotoxin, cylindrospermopsin in the sediment samples and was attributed to the cyanobacteria species, Raphidiopsis raciborskii (Table 3).

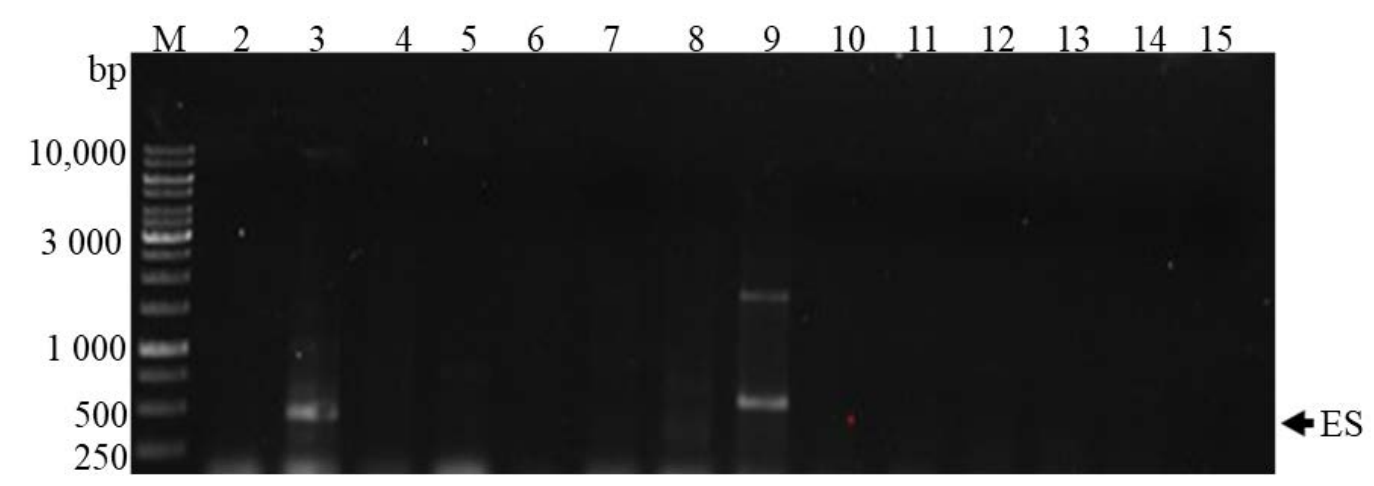

Figure 6. PCR products using PKS primers for cylindrospermopsin polyketide synthetase gene. ES (estimated fragment); M (Standard Marker), 2-18 Samples number. Lane 2 = Notwane River; 3 = Sand River upstream; 4 = Mogalakwena River; 5 = Mawoni River; 6 = Lephalale River; 7 = Mokolo River; 8 = Crocodile River downstream of Hartbeespoort Dam; 9 = Nzhelele River downstream; 10 = Sand River downstream; 11 = Crocodile River downstream (near the bridge on road D1235); 12 = Nzhelele River upstream; 13 = Mzingwane River; 14 = Shashe River; 15 = Limpopo River (next to Thuli Coal Mine). 
Table 3. Results from the BLAST search showing the similarity between the GenBank sequences and sample sequenced using PKS and HEP primers for toxin gene identification.

\begin{tabular}{|c|c|c|c|c|}
\hline Primers & Sample No & Similarity \% & Species Similar to & Accession No \\
\hline \multirow{9}{*}{ PKS } & S3 & 100 & Aphanizomenon sp. 10E6 & GQ385961.1 \\
\hline & S3 & 100 & Raphidiopsis curvata & KJ139745.1 \\
\hline & S3 & 100 & Cylindrospermopsis raciborskii & AF160254.1 \\
\hline & S3 & 100 & Arthrospira sp. str. PCC 8005 & FO818640.1 \\
\hline & S3 & 100 & Nostoc sp. NIES-4103 & AP018288.1 \\
\hline & S9 & 93 & Calothrix sp. 336/3 & СР011382.1 \\
\hline & S9 & 89 & Oscillatoria nigro-viridis PCC 7112 & СР003614.1 \\
\hline & S9 & 100 & Gloeocapsa sp. PCC 7428 & СР003646.1 \\
\hline & S9 & 100 & Cylindrospermum sp. NIES-4074 & AP018269.1 \\
\hline \multirow{10}{*}{ HEP } & S8 & 100 & $\begin{array}{l}\text { Uncultured Microcystis sp. clone msp } \\
\text { microcystin synthetase E (mcyE) gene, partial cds }\end{array}$ & KF687998 \\
\hline & S8 & 100 & Microcystis panniformis FACHB-1757 & СР011339.1 \\
\hline & S8 & 100 & Microcystis aeruginosa PCC 7806 & AF183408.1 \\
\hline & S8 & 100 & Nostoc sp. 152 & КС699835.1 \\
\hline & S8 & 100 & Planktothrix rubescens NIVA-CYA 98 & AM990462.1 \\
\hline & S13 & 100 & Nostoc sp. 152 & КС699835.1 \\
\hline & S13 & 100 & Planktothrix rubescens NIVA-CYA 98 & AM990462.1 \\
\hline & S13 & 100 & Uncultured Microcystis sp. from Uganda & FJ429839.2 \\
\hline & S13 & 100 & Microcystis aeruginosa PCC 7806SL & СР020771.1 \\
\hline & S13 & 100 & $\begin{array}{l}\text { Uncultured Microcystis sp. clone mw } \\
\text { microcystin synthetase E (mcyE) gene, partial cds }\end{array}$ & KF687997.1 \\
\hline
\end{tabular}

The HEP primer pair produced two positive results for samples from Crocodile River (S8) and Mzingwane River (S13). Both positive results were attributed to the presence of toxigenic Microcystis sp. (Table 3). The latter is an important finding, since water supplies from the Limpopo River basin are used by water utilities for drinking water supplies, and by commercial and subsistence irrigation farmers for the production of food crops and livestock watering (Figure 7).

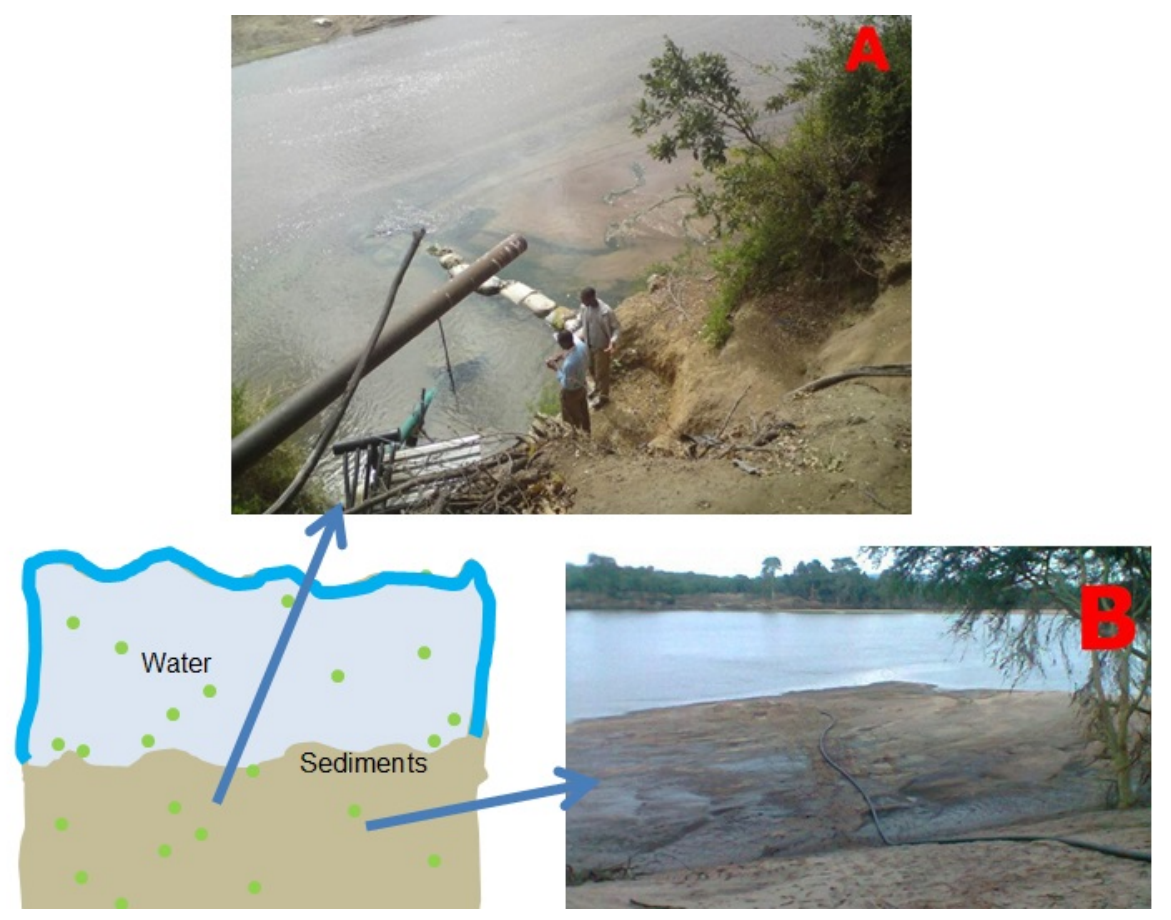

Figure 7. A scenario involving boreholes drilled inside the Limpopo river channel and contamination with cyanobacteria (green dots) cysts and akinetes for (A) irrigation farmers \& (B) water utility raw water supply for human consumption. 


\subsection{Phylogenetic Relationship}

The relationship between the samples and their most similar species, as noted from the BLAST search, was confirmed by the phylogenetic tree, and the relationships between some cyanobacteria species from different samples (Figure 8). The first confirmation was on the similarity of samples from the Crocodile River (S8) downstream Hartbeespoort Dam and the Shashe River (S14) to Leptolyngbya boryana with $99 \%$ bootstrap confidence. Secondly the similarity of the Musina borehole extraction (S16) sample to Alkalinema pantanalense, with $98 \%$ bootstrap, and the similarity of the samples from Sand River (S3) upstream. Another similarity was evident in the Nzhelele River (S9) downstream near Tshipise and Mokolo River to Synechocystis sp. PCC 6803. The other similarity was Mawoni River (S5) downstream of Makhado oxidation pond to Leptolyngbya sp. with $97 \%$ bootstrap confidence, with the Notwane River (S2) to uncultured Leptolyngbya sp. with $99 \%$ bootstrap confidence, and lastly the Sand River (S10) downstream to the filamentous cyanobacterial species Spirulina laxissima with $100 \%$ bootstrap confidence.

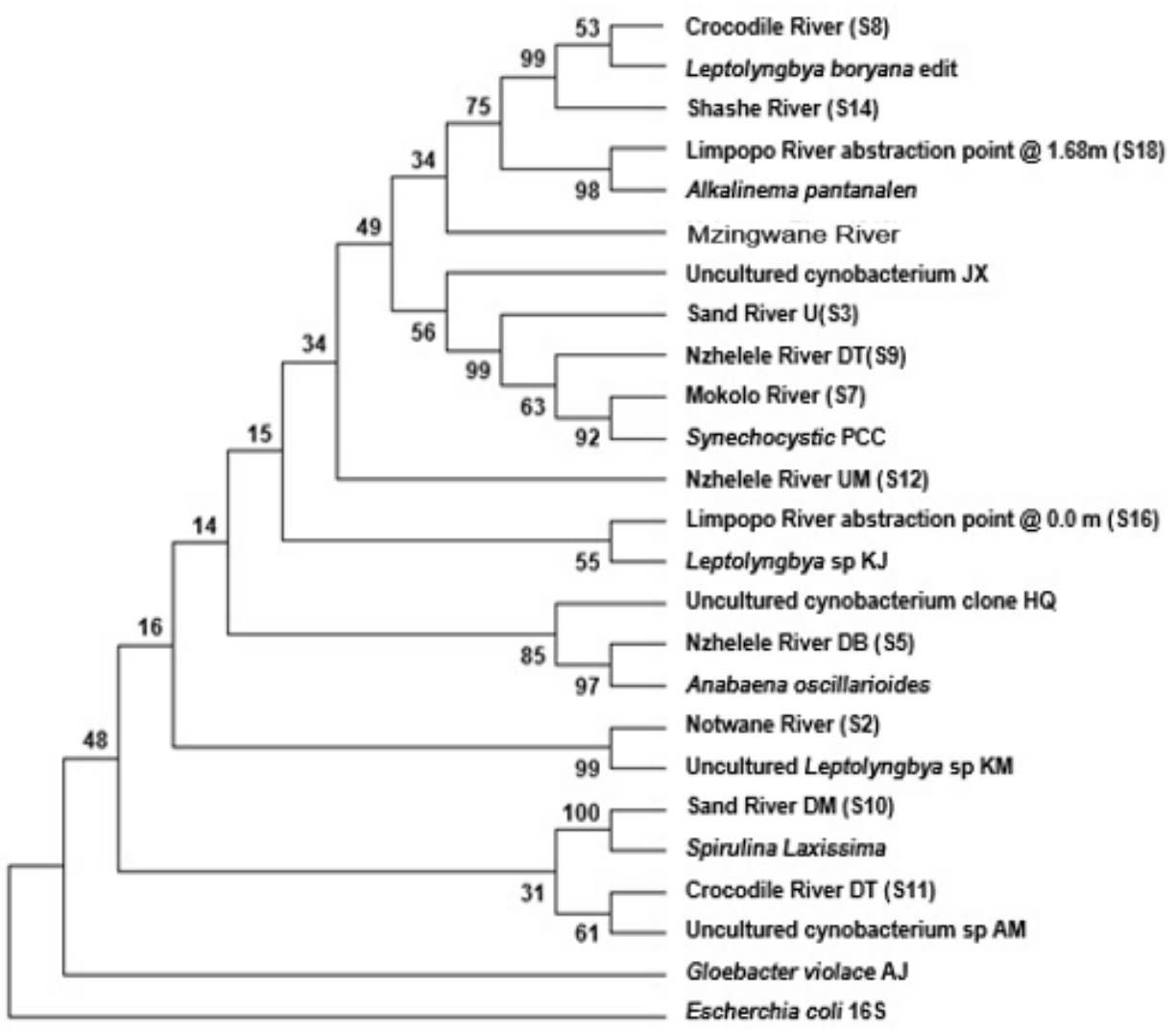

Figure 8. The evolutionary history was inferred using the Neighbor-Joining method. U: upstream; UM: Upstream; DT: Downstream; DB: Downstream; DM: downstream; PCC: Pasteur Culture Collection of Cyanobacteria.

However, the detection of cyanobacteria at the Musina borehole extraction (S16) and the Sand River (S3) may suggest that there were aquatic animals such as fish, dispersal or transportation of cyanobacterial cells from the entrance (mouth) of Sand River towards the Musina abstraction point (Figure 9). In simple terms, there was an upstream transport of cyanobacteria species that was facilitated by aquatic animals, but this requires further investigation. The other matches from the BLAST search include the Musina Borehole extraction point (S16) to Leptolyngbya sp., as well as the Crocodile River (S11) near bridge on road D1235 and upstream of Thabazimbi town to uncultured Cyanobacteria clone. However, the latter bootstrap confidence levels were between 55 and $61 \%$, respectively. It was evident from the data that a divergence matrix can be used to verify the truth of 
both the BLAST search and phylogenetic tree. The divergence matrix confirmed that cyanobacteria from the Crocodile River (S8) downstream of Hartbeespoort Dam and from Shashe River (S14) were the same Leptolyngbya boryana species, since they both showed at least $98 \%$ similarity to this species.

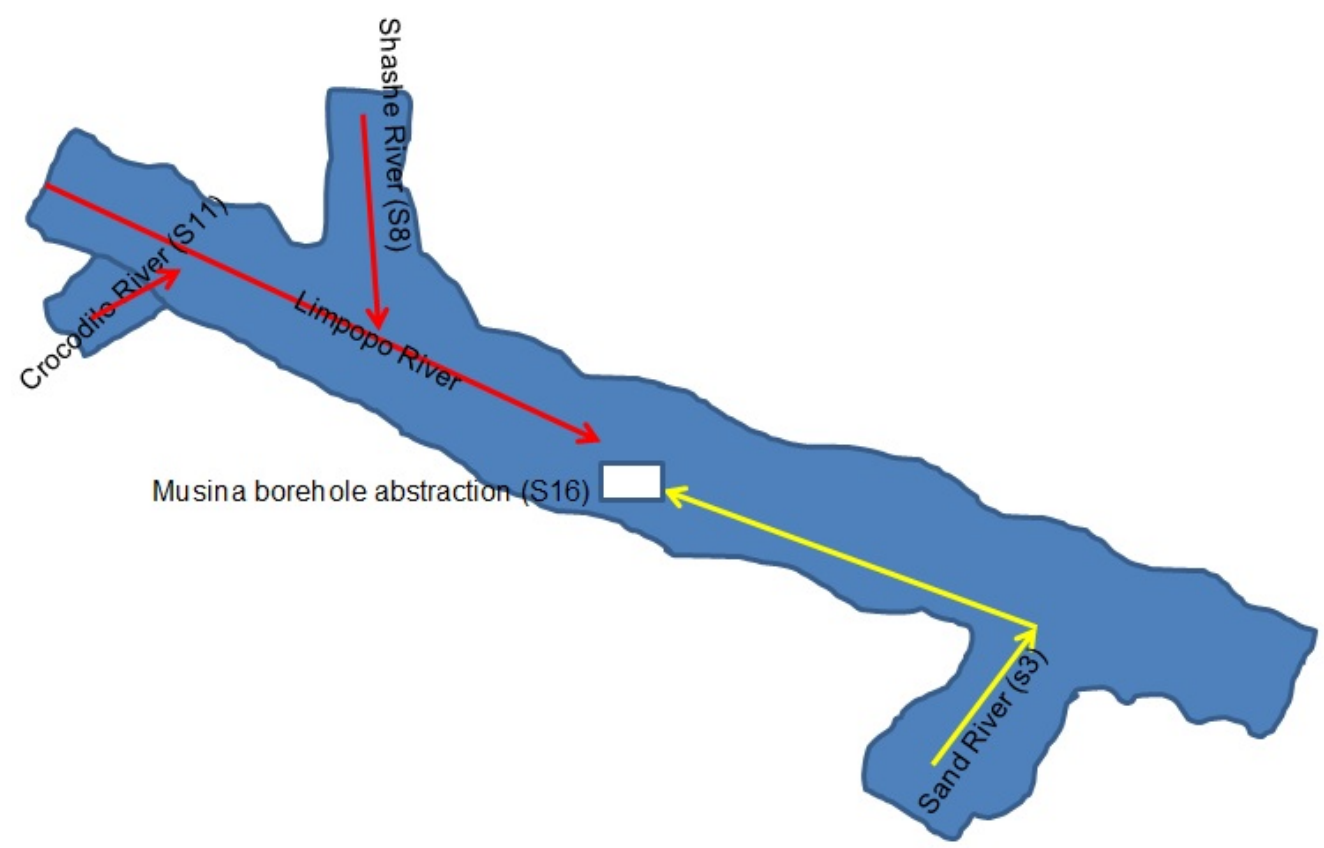

Figure 9. A scenario involving the movement of cyanobacteria species during water flows in the Limpopo River (red arrow) towards the Musina abstraction borehole (White Square). The possible upstream movement (yellow arrow) from the Sand River (S3) to the Musina borehole (S16) may involve cyanobacteria 'hitching a ride' on aquatic animals such as fish and crocodiles.

Thus, the current study indicates that there is DNA evidence to suggest a similarity between the cyanobacteria at the Musina abstract point and that from the Crocodile River system. The possibility thereof lies in the fact that the Musina abstraction point was downstream from the Crocodile River, which flows into the Limpopo River (Figure 7). However, samples from the Nzhelele River upstream near the Mphephu Resort and Mzingwane River (Zimbabwe) did not match. Nevertheless, the relationship between the cyanobacteria species from specific locations were identified by a Divergence Matrix (Table 4). In addition, the same species were detected by the difference co-efficient of 0.00 , whereas completely unrelated species were detected by the co-efficient of 1.00 .

Table 4. Divergence matrix for reflection of similarity.

\begin{tabular}{|c|c|c|c|c|c|c|c|c|c|c|c|c|c|}
\hline & S2 & S3 & S5 & S7 & S8 & S9 & S10 & S11 & S12 & S13 & S14 & S16 & S18 \\
\hline Notwane River (S2) & - & & & & & & & & & & & & \\
\hline Sand River (S3) & 0.216 & - & & & & & & & & & & & \\
\hline Nzhelele River (S5) & 0.191 & 0.187 & - & & & & & & & & & & \\
\hline Mokolo River (S7) & 0.167 & 0.064 & 0.130 & - & & & & & & & & & \\
\hline Crocodile River (S8) & 0.166 & 0.160 & 0.149 & 0.119 & - & & & & & & & & \\
\hline Nzhelele River (S9) & 0.184 & 0.095 & 0.152 & 0.028 & 0.140 & - & & & & & & & \\
\hline Sand River (S10) & 0.155 & 0.216 & 0.153 & 0.156 & 0.169 & 0.169 & - & & & & & & \\
\hline Crocodile River (S11) & 0.257 & 0.295 & 0.280 & 0.244 & 0.278 & 0.254 & 0.236 & - & & & & & \\
\hline Nzhelele River (S12) & 0.391 & 0.394 & 0.365 & 0.351 & 0.350 & 0.361 & 0.364 & 0.492 & - & & & & \\
\hline Mzingwane River (S13) & 0.190 & 0.180 & 0.184 & 0.130 & 0.134 & 0.139 & 0.168 & 0.267 & 0.377 & - & & & \\
\hline Shashe River (S14) & 0.173 & 0.163 & 0.156 & 0.119 & 0.006 & 0.140 & 0.173 & 0.278 & 0.355 & 0.134 & - & & \\
\hline Musina borehole (S16) & 0.376 & 0.359 & 0.312 & 0.314 & 0.342 & 0.321 & 0.343 & 0.414 & 0.555 & 0.371 & 0.347 & - & \\
\hline Musina borehole (S18) & 0.183 & 0.184 & 0.179 & 0.136 & 0.128 & 0.150 & 0.186 & 0.285 & 0.366 & 0.173 & 0.131 & 0.348 & _ \\
\hline
\end{tabular}


The cyanobacteria species from the Crocodile River (S8) were the same species as the cyanobacteria from the sampled Shashe River (S14), since they had less than $1 \%$ difference $(0.006)$. This may have been expected, since the Shashe River is downstream of the Crocodile River (Figure 9). The cyanobacteria species from the Mokolo River (S7) and the Nzhelele River (S9) share undetectable differences. However, a comparison shows that there was a difference between the cyanobacteria species from the Notwane (S2) and Mawoni Rivers (S5). The cyanobacteria which differed the most from the other species were the cyanobacteria species from the Notwane River (S2) and Limpopo River (S16). The latter sampling sites' species also differed from each other, with $28 \%$, while their comparison co-efficient range from 0.17 to 0.28 . Furthermore, the Nzhelele River upstream (S12) and Limpopo River (S16) species differed from each other with $28 \%$, while their comparison co-efficient ranged between 0.312 to 0.492 , which was the highest for all species.

The first observation was that Uncultured Cyanobacterium clone HQ189039.1 could not be used for the phylogenetic tree because of its length (about $480 \mathrm{bp}$ ). This is because the $t$ complete deletion option of gaps and missing information in MEGA 7 [35] was used. The second observation was that two outgroup sequences had been used in phylogenetic alignment.

\section{Discussion}

The physical chemical data generated in the current study shows that there were large variations in sediment EC between the different sampling sites while the sediment temperature was $\geq 22^{\circ} \mathrm{C}$ during all the sampling trips. High temperatures arising from climate change have been reported as an important factor in the global expansion of harmful algal bloom worldwide [36]. Rising temperature exceeding $20{ }^{\circ} \mathrm{C}$ can promote the growth rate of cyanobacteria, whereas the growth rate other freshwater eukaryotic phytoplankton decreases, which is regarded as a competitive advantage for cyanobacteria [37]. A study by $\mathrm{O}^{\prime} \mathrm{Neil}$ et al. [9] reported that higher temperatures promote the dominance of cyanobacteria and favor the production of microcystins, as well as resulting in an increase in their concentration.

The high $\mathrm{pH}$ value measured during the current study may have a competitive advantage for many cyanobacteria, because of their strong carbon-concentrating abilities compared to eukaryotic phytoplankton species [38]. A laboratory experiment carried out by Jahnichen et al. [39] on Microcystis aeruginosa showed that microcystin production started when $\mathrm{pH}$ exceeded 8.4, thus indicating a lack of free carbon dioxide $\left(\mathrm{CO}_{2}\right)$.

The increased input of nutrients into the surface water is the main factor responsible for massive proliferations of cyanobacteria in fresh water, brackish and coastal marine ecosystems. However, phosphorus and nitrogen nutrients in high levels lead to accelerated growth of cyanobacteria $[40,41]$.

Thus, the higher concentration of phosphorus measured in the current study downstream of the Siloam oxidation ponds may be due to the discharge of sewage effluent [42]. The low concentration of phosphorus measured in the Lephalale River (S6) is possibly related to less anthropogenic land use activities upstream of this sample site [43]. Phosphorus has been implicated more widely than nitrogen as a limiting nutrient of phytoplankton and cyanobacteria in freshwater systems [44]. A minimum amount of phosphorus entering or becoming soluble in a water body can trigger a significant algal bloom [45]. The impact of excess phosphorus on receiving rivers or streams is evident from the green coloration of surface water owing to the presence of phytoplankton or cyanobacteria. The Limpopo River (S1) receives inflows from both the Notwane and Crocodile Rivers, and these contribute significantly to the phosphorus loading of the Limpopo River. Furthermore, the main source of phosphorus in the Notwane River (S2) is the municipal discharge from the Glen Valley sewage plant and agricultural runoff from irrigated farms and livestock ranching in the river's catchment $[23,46]$. The Crocodile River receives sewage effluent from upstream catchment land use activities such as the discharge of sewage effluent into tributaries of the Crocodile River, discharge into Crocodile River itself and agricultural runoff $[47,48]$. The Sand River (S3) receives municipal nutrient discharge from the Polokwane sewage plants and rainwater runoff that would contain fertilizer from agricultural activities 
in the river sub catchment [49]. The sample point on the Mogalakwena River (S4) was downstream of the Mokopane, Modimolle and Mookgophong towns' sewage plants, golf courses, game farming, livestock farming and irrigated farmlands [50]. After the town of Mokopane, the Nyl River is renamed to the Mogalakwena River. The Mzingwane River (S13) receives municipal discharge from the Filabusi, Gwanda and West Nicholson sewage plants and agricultural runoff from irrigated farms and livestock ranching in these areas [51], and this may be attributed to sewage plants upstream in Francistown and agricultural runoff from irrigated farms and livestock ranching [48,52]. These rivers are part of the Limpopo River's tributaries and contribute to the successive loading of phosphorus in the Limpopo River (S15-S16) [53].

The highest value of nitrogen was recorded in the Nzhelele River (S12) near the Mphephu Resort and downstream of Siloam hospital oxidation ponds. The reason for the detection of these high nitrogen values is possibly related to the discharge of sewage effluent from the Siloam hospital [42]. Filamentous cyanobacteria can obtain nitrogen by fixing the atmospheric nitrogen gas and converting it to nitrate for their growth [54]. Nitrogen is a common gas (79\%) that is found in the atmosphere. Thus, cyanobacteria genera such as Anabaena are able to utilize atmospheric nitrogen in addition to nitrate originating from the river sediments [54,55]. The other sample sites with nitrates in excess of $2 \mathrm{mg} / \mathrm{L}$ are Sand River (S4), Mawoni River (S5), Crocodile River (S11), Mzingwane River (S13), and Limpopo River (S16 to S18). All these tributaries have one in common source of pollution upstream, namely, a municipal sewage plant, and are also surrounded by farmland where commercial irrigation farming is practiced, as in the case of the Crocodile, Notwane, Shashe, Mzingwane and Sand rivers. Subsistence agriculture is practiced in the case of the Mawoni and Mzingwane rivers [46,48-52]. The Crocodile River also receives inflows from eutrophic Hartbeespoort Dam [47]. The Limpopo River (S16) is downstream of all the sample points, and this shows the cumulative discharge of nitrates originating from the tributaries, causing an increase in concentration of nitrogen. The Musina local municipality has drilled 8 boreholes in the Limpopo river bed, and most of these boreholes are located close to S16, and thus there is a possibility of cyanotoxin contamination of the borehole water [56]. Thus, further research is required to determine if there is cyanotoxin contamination of borehole water.

Botha and Oberholster [57] performed a survey of South African freshwater bodies between 2004 and 2007, using RT-PCR and PCR technology to distinguish toxic and non-toxic Microcystis strains bearing mcy genes, which correlate with their ability to synthesize the cyanotoxin microcystin. The study revealed that $99 \%$ of South Africa's major impoundments contained toxicogenic strains of Microcystis. The study by Su et al. [58] in the Shanzi impoundment, China showed that the sediments were the source of cyanobacteria inoculum. This implies that the cyanobacteria flocculates in the sediments during periods of adverse environmental conditions, such as cessation in river flows. These cyanobacteria cysts or spores then reactivate during periods of river flow. The cyanobacteria cysts and spores are related to the summer environmental conditions in the Limpopo river basin, where the majority of tributaries are perennial and river flows commence during the period of summer rainfall. The river flows disturb the sediments, thus bringing into the water column the cyanobacteria cysts or spores [58]. The source of nutrients in the Limpopo river basin may be attributed directly to sewage discharge of municipal waste water plants such as Glen Valley and Mahalpye on the Botswana side, and on the South Africa side, the western and northern parts of the city of Johannesburg to the town of Musina and indirectly to the agricultural practices of fertilizer application and animal waste [46,48-52].

Cyanobacteria undergo distinct developmental stages [59]. For example, they differentiate into resting cells, spores, akinetes and cysts which represent a survival strategy under unfavorable environmental conditions [55,60]. Under favorable conditions, the cell will germinate again [61]. The ability of cyanobacteria to adapt to adverse dry periods allows them to inhabit the river sediments, as shown by studies by Perez at al. [60], Kim et al. [55] and this study (Figure 10). The study of Kim et al. [55] further illustrated the viable nature of cysts and akinetes in providing the next inoculum 
of Microcystis, Anabaena, Aphanizomenon and Oscillatoria is Bukhan, Namhan Rivers and Lake Paldang and Kyeongan stream, in South Korea.
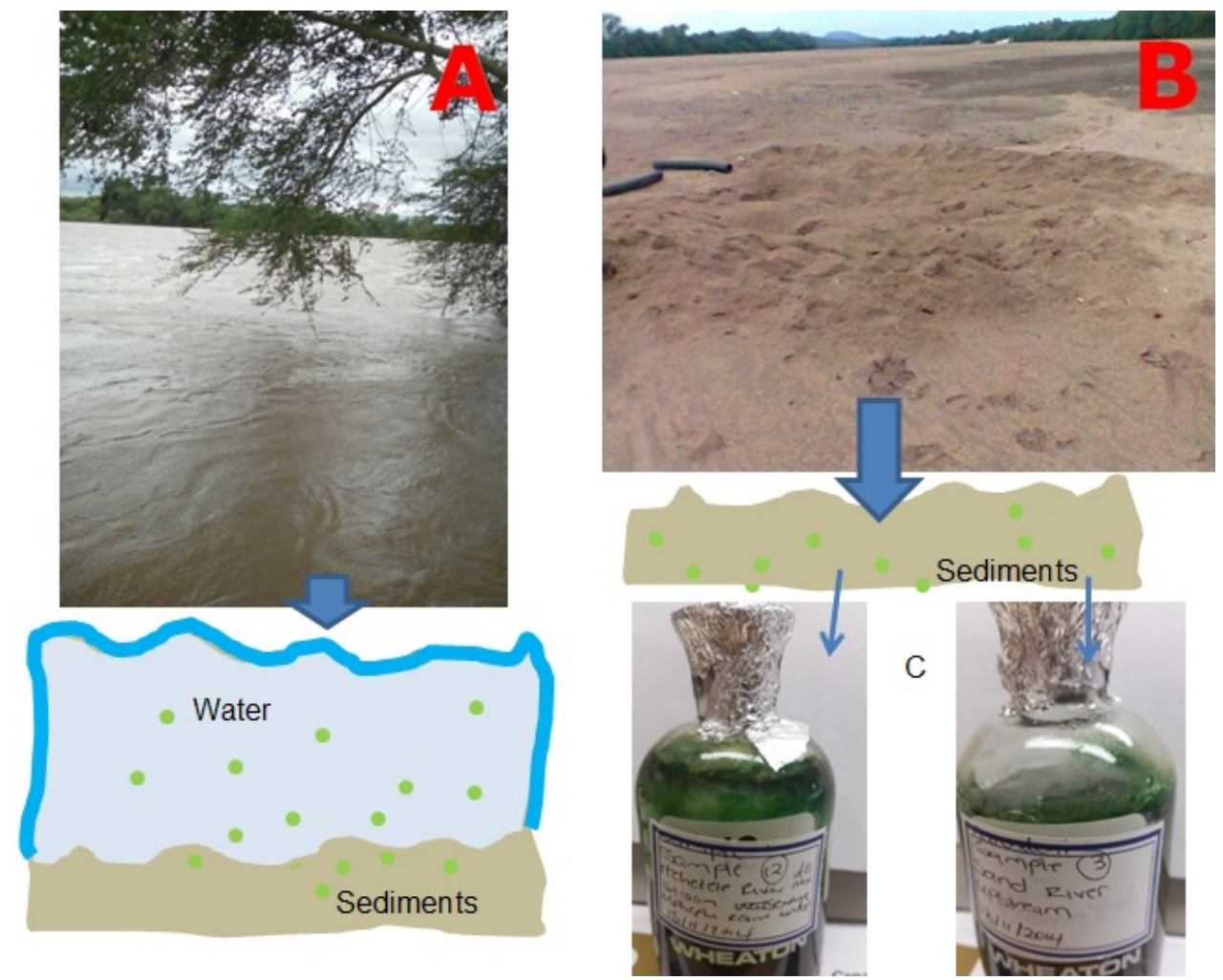

Figure 10. Scenario involving sedimentation of cyanobacteria (green dots) cysts and akinetes (A) during flood and flow conditions in Limpopo River and (B) during non-flow (DRY) conditions in the Limpopo River and (C) growth of cyanobacteria under continuous lighting and provision of BG medium at room temperature.

As expected, the toxigenic Microcystis species was found in the Crocodile River, downstream of the Hartbeespoort Dam, a eutrophic water impoundment known for the regular occurrence of Microcystis dominated harmful algal blooms [40]. However, our two toxigenic Microcystis strains were different from the seventeen toxigenic Microcystis strains studied by Mbukwa et al. [24] from the Hartbeespoort Dam. The differences may be explained by the different use of mcy primers in identifying the genes expressing toxicity and differences in experimental approach. Our study on the $m c y A-C d$ primer did not amplify, whereas Mbukwa et al. [24] reported the amplification of the $m c y A-C d$ genes, showing seventeen toxigenic Microcystis strains. However, during our study, the mcyE genes were positively expressed with the HEP primer and did amplify, but the outcomes were also different from the toxigenic Microcystis strains studies by Mbukwa et al. [24]. During our study, the total genomic DNA was not extracted directly from the sediments, but from cyanobacteria that was cultured in the laboratory. Laboratory culture conditions have been known to alter the toxicity of Microcystis species, as shown by the study of Scherer et al. [62]. In the latter study, the authors mimicked a temperature increase of $10{ }^{\circ} \mathrm{C}$. Under these increased temperature conditions, Microcystis was able to express $m c y B$ gene related to production of toxicity instead of the $m c y D$ gene. This may imply the biodiversity of toxigenic Microcystis strains in Hartbeespoort Dam and the Crocodile River and the Limpopo River basin.

Mbukwa et al. [24] used DNA molecular techniques to identify the two species of Microcystis as M. aeruginosa (origins from Hartbeespoort Dam, South Africa) and M. novacekii (origins from Phakalane effluent, Gaborone, Botswana). The molecular techniques showed the presence of the 
mcy genes responsible for microcystin encoding, thus confirming that the two Microcystis species did have the potential to produce toxins. The Phakalane pond effluent is discharged into the Notwane River, a tributary of the Limpopo [23]. An earlier study by Basima [51] upstream of the Mzingwane S13 sample point showed the abundance of cyanobacteria genera dominated by Microcystis species followed by Anabaena and Nostoc species in water impoundments situated inside the Mzingwane River. In the lower Limpopo River, situated in Mozambique, at the Chokwe irrigation scheme, which receives irrigation waters from Maccaretane Dam, Pedro et al. [25] reported the presence of Microcystis species and microcystin-LR concentrations of $0.68 \mathrm{ppb}$. The latter concentrations were linked to the presence of the $m c y B$ and $m c y A$ genes in collected water samples. Mikalsen et al. [63] identified eleven Microcystis species containing different variants of the $m c y A B C$ (toxic species), and seven Microcystis species that lacked the $m c y A B C$ gene (non-toxic species). A study by Davies et al. [64] on four temperate lakes in the northwest of the USA showed that the increase in water temperature contributed to an increase in toxic Microcystis species (possessing the mcyD gene). Yamamoto [65] and Oberholster et al. [66] have shown that the Microcystis species adopt survival strategies to mitigate harsh external environments such as reduced river flow, a major characteristic of the Limpopo River, by sinking into the sediments.

The Limpopo river basin is characterized by extreme weather events such as heatwaves, floods and drought [67]. Could the latter, including extreme heatwaves, possibly have contributed to toxic or non-toxic Microcystis species? The presence of microcystins in the rivers may constitute a health risk, especially for the communities that may be in contact or drink the polluted water without any form of treatment or suitable treatment that is able to remove the toxins in the water. The convectional method for water treatment is not convenient for the removal of microcystins in water [68]. Drinking water treatment processes might trigger the release of hepatoxin into drinking water by disrupting the trichomes of cyanobacteria [69]. Thus, the presence of cyanotoxins can also poison the livestock and game animals (wildlife) in transfrontier parks such as Kruger National Park, Gona-re-zhou National Park and Mapungubwe National Park [70]. Microcystins have already been implicated in the death of wildlife in the Kruger National Park [71]. Cyanotoxins have been implicated in the negative growth (stunting) of plants, and this may have serious repercussions for irrigation farmers [72].

The evolutionary tree constructed could not be used for phylogenetic purposes because of two important reasons: (1) the number of samples used for PCR per river site was not enough to make a conclusive argument; and (2) the cyanobacteria were the expected products which needed to be identified. Hence the tree was used to verify the identification as done by BLAST search; however, the phylogenetic relationship was basically done by divergence matrix, and combined discussion followed the divergence matrix.

\section{Conclusions}

Many countries in Africa have reported cases of intoxication and death of animals that may have been caused by cyanobacterial toxins. Monitoring and or reducing the nutrient loads into the river system will decrease the threat of cyanobacteria blooms to human and animal health. The results obtained in the current study indicated the presence of toxic and non-toxic cyanobacteria species in the bottom sediments of the Limpopo River and its tributaries. Molecular tools were used in the present study to determine non-toxic and toxic cyanobacteria based on genes that produce proteins related to cyanotoxins. The presence of nutrients, phosphates and nitrates in the river sediments did stimulate the growth of the cyanobacteria during summer river flow periods. Furthermore, the expression of genes that have the potential to produce toxins, for example cylindrospermopsin and microcystin/nodularin in the river sediments indicate a potential risk to the environment and human health. The cyanotoxins are harmful to humans who consume the water originating from boreholes located inside the Limpopo River basin or drilled along the Limpopo River basin. Secondly, the water supplies from the Limpopo River basin are used by commercial and subsistence irrigation farmers for growing food crops and livestock watering. Thus, presence of cyanotoxins can also adversely affect the livestock and game animals (wildlife) in transfrontier parks. Furthermore, cyanotoxins have been 
implicated in the negative growth (stunting) of plants, and this may have serious repercussions for the irrigation farmers in this region.

\section{Future Research Work}

Further studies are required to determine the level and types of cyanotoxins in the Limpopo river basin, since water resources are used for a variety of purposes, such as human consumption, irrigation, livestock and wildlife watering and impact if any on aquatic biodiversity.

\section{Materials and Methods}

\subsection{The Study Area}

The study area is the Limpopo River and its major tributaries (Figure 11). The Limpopo River basin consists of four countries: Botswana, South Africa, Zimbabwe and Mozambique [73].

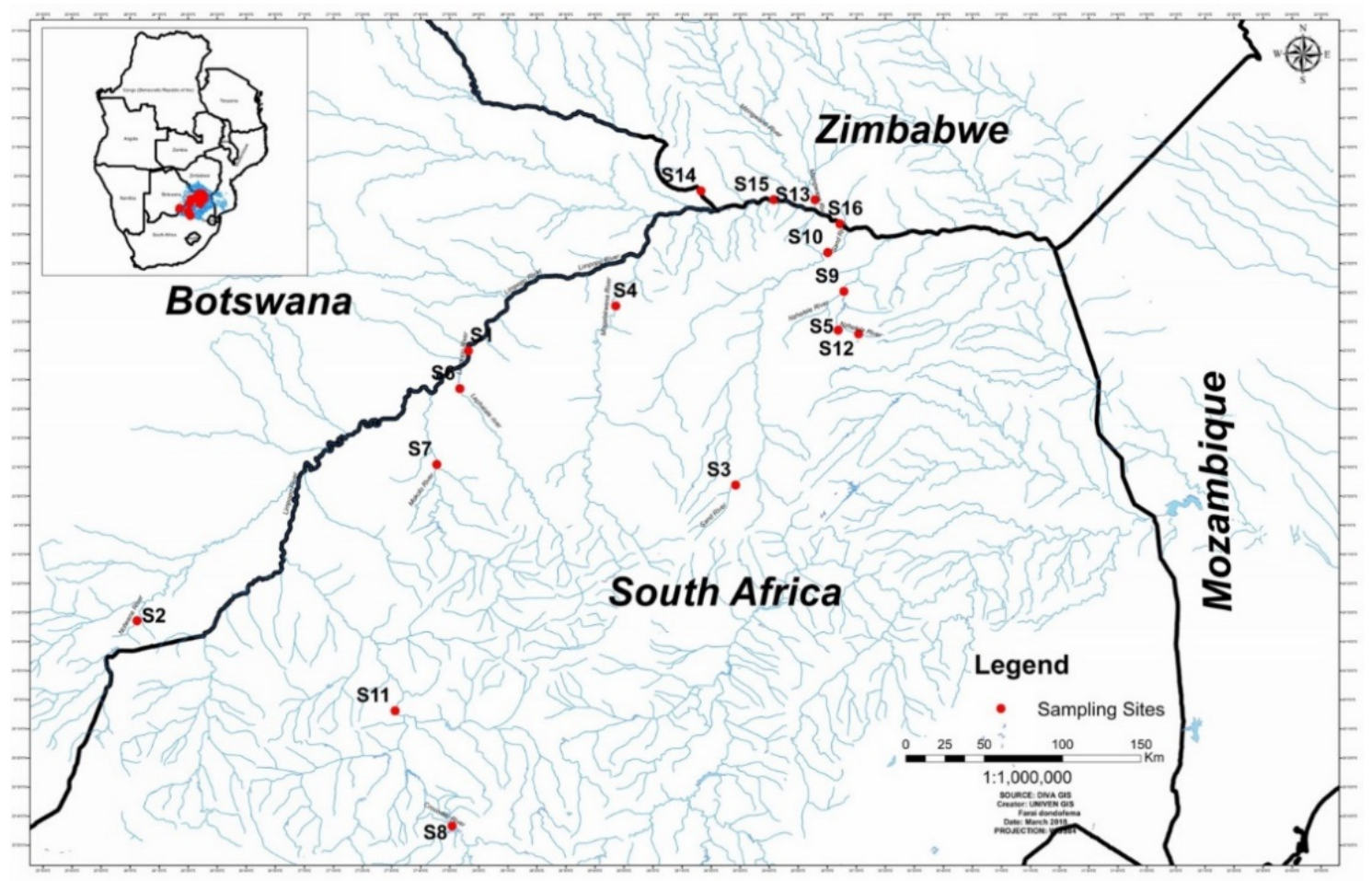

Figure 11. The location of sediment sample sites on some of the tributaries of the Limpopo River.

The Limpopo River basin is an arid to semi-arid region where water is of strategic importance to development. Water has a potential limiting effect on all future development in the region. The Limpopo River basin is home to almost 14 million people in four riparian states [74].

\subsection{Sampling Sites and Sampling Methods}

Sampling sites were selected with the following in mind: (a) accessibility, biotype, e.g., sandy bottom sediment; (b) canopy cover and depth, and (c) river sites receiving inflows of municipal sewage discharges. The 18 grab river sediment samples were collected in October and November 2014. The river sediment samples $(\sim 500 \mathrm{~g})$ were collected in sterile glass containers from rivers and tributaries of the Limpopo River (Table 5). The use of river sediments was chosen because most suspended material, including cyanobacteria spores and cysts, settles at the river bottom, where they become part of the sediments in river systems. 
Table 5. The location of sample sites and sample codes.

\begin{tabular}{cc}
\hline River Names & Samples Numbers \\
\hline Limpopo River (Groblers' bridge) & $\mathrm{S} 1$ \\
Notwane River (Odi Bridge-Matabeleng) & $\mathrm{S} 2$ \\
Sand River upstream & $\mathrm{S} 3$ \\
Mogalakwena River next to Tolwe & $\mathrm{S} 4$ \\
Mawoni River downstream Makhado oxidation ponds & $\mathrm{S} 5$ \\
Lephalale river & $\mathrm{S} 6$ \\
Mokolo River & $\mathrm{S} 8$ \\
Crocodile River downstream Hartbeespoort dam & $\mathrm{S} 9$ \\
Nzhelele River downstream near Tshipise & $\mathrm{S} 10$ \\
Sand River downstream (at bridge on N1 road towards Musina) & $\mathrm{S} 11$ \\
Crocodile River downstream (near bridge on road D1235) near Thabazimbi & $\mathrm{S} 12$ \\
Mzhelele River upstream near Mphephu resort (downstream of Siloam oxidation ponds) & $\mathrm{S} 13$ \\
Mzingwane River (Zimbabwe) & $\mathrm{S} 14$ \\
Shashe River (near Irrigation scheme, Zimbabwe) & $\mathrm{S} 15$ \\
Limpopo River next to Thuli coal mine & $\mathrm{S} 16$ \\
Limpopo River abstraction point @ $0.0 \mathrm{~m}$ & $\mathrm{~S} 17$ \\
Limpopo River abstraction point @ $1.0 \mathrm{~m}$ & $\mathrm{~S} 18$ \\
Limpopo River abstraction point @ $1.68 \mathrm{~m}$ &
\end{tabular}

\subsection{Physical-Chemical Measurements}

In the laboratory, the physical measurement of $\mathrm{pH}$, Total dissolved solids (TDS) and electric conductivity (EC) was carried out using Portable $\mathrm{pH}$ meter Crison MM40 (Crison Instruments SA, Alella, Spain) on the river sediments. It was first calibrated as per the manufacturer's guidelines. The $\mathrm{pH}, \mathrm{TDS}$ and EC of the sediments were determined by the method of Islam et al. [75], in which $50 \mathrm{~g}$ of sediment was mixed with $50 \mathrm{~mL}$ of distilled water in a $100 \mathrm{~mL}$ beaker to produce a ratio of 1:1. The mixture was stirred with a stirring rod to homogenize the mixture and was then left for $30 \mathrm{~min}$ to settle. EC, pH and TDS were then measured by inserting the electrodes in the soil solution and readings were taken.

\subsection{Nutrient Analysis}

The air-dried sediments were subjected to nutrient analysis, and this involved determining Total Phosphate (TP) and Total Nitrogen (TN). The analyses were done in duplicates and the aliquot of all digested samples was analyzed with Merck Spectroquant ${ }^{\circledR}$ Pharo 100 spectrophotometer with a wavelength of 320-1100 nm purchased from Merck (Darmstadt, Germany).

\subsubsection{Total Phosphorus Analysis}

Total phosphorus was determined by using the perchloric acid digestion method as described by American Public Health Association (APHA) [76]: $2 \mathrm{~g}$ of air-dried sediment was acidified to methyl orange with concentrated $\mathrm{HNO}_{3}$, another $5 \mathrm{~mL}$ of concentrated $\mathrm{HNO}_{3}$ was added and evaporated on a hotplate until dense fumes appeared. $10 \mathrm{~mL}$ each of concentrated $\mathrm{HNO}_{3}$ and $\mathrm{HClO}_{4}$ was added and evaporated gently until dense white fumes of $\mathrm{HClO}_{4}$ appeared. The solution was then neutralized with $6 \mathrm{~N} \mathrm{NaOH}$ and made up to $100 \mathrm{~mL}$ with distilled water. Aliquots of the samples were then analyzed with spectrophotometer using phosphate cell test kit (Merck, Darmstadt, Germany).

\subsubsection{Total Nitrogen Analysis}

Total nitrogen was determined per APHA [76] as ammonia: $1 \mathrm{~g}$ of each air-dried sediment sample was treated with $2 \mathrm{~mL}$ of sulphuric acid. The sample was heated on a hotplate for $2 \mathrm{~h}$. Aliquots of $50 \mathrm{~mL}$ of deionized water were added to each sample. The sample was filtrated through No. 41 Whatman filter paper. The filtrate of each sample was made up to $250 \mathrm{~mL}$ with deionized water and $55 \mathrm{~mL}$ of $1 \mathrm{M}$ sodium hydroxide solution. Aliquots of the samples were then analyzed with spectrophotometer using a nitrate cell test kit (Merck, Darmstadt, Germany). 


\subsection{Data Analysis}

The physico-chemical and cyanotoxin measurements were conducted in duplicates, and the standard deviation and mean were calculated, using a Microsoft (MS) Excel 2010 spreadsheet for each sampling point. The graphs were plotted using MS Excel.

\subsection{The Culture of Cyanobacteria Species in River Sediments}

The modified BG11 medium was laboratory-prepared as per Gumbo et al. [77] for cyanobacteria culturing. The $200 \mathrm{~mL}$ sterile modified BG11 medium was transferred to sterile $250 \mathrm{~mL}$ laboratory jars under sterile conditions and then $200 \mathrm{~g}$ of river sediments was added. A total of 18 laboratory jars were incubated for 30 days under continuous light (1100 lux) fluorescent lamps at room temperature. The harvested cyanobacteria cells were subsequently used for identification and molecular characterization.

\subsection{The Identification of Cyanobacterial Species Using the FlowCam}

The harvested cyanobacteria cells were used to identify cyanobacterial species present in the samples, a bench top FlowCam (Model vs. IV) was used. In the FlowCam system, the sample is drawn into the flow chamber by a pump. Using the laser in trigger mode, the photomultiplier and scatter detector monitor the fluorescence and light scatter of the passing particles. When the particles passing through the laser fan have sufficient fluorescence values and/or scatter, the camera is triggered to take an image of the field of view. The fluorescence values were then saved by the Visual Spreadsheet. The computer, digital signal processor, and trigger circuitry work together to initiate, retrieve and process images of the field of view. Groups of pixels that represented the particles were then segmented out of each raw image and saved as a separate collage image. The image was then captured and compared to the image of cyanobacteria as per the procedure of van Vuuren et al. [78].

\subsection{The Identification of Cyanobacterial Species Using Molecular Characterization}

The cyanobacteria cells were harvested and used for molecular characterization as per the following procedures, as outlined below:

\subsubsection{DNA Extraction and Purification}

Samples were freeze-dried and stored at $-20{ }^{\circ} \mathrm{C}$ for DNA extraction. Total genomic DNA was extracted using the ZR-Duet ${ }^{\mathrm{TM}}$ DNA/RNA Miniprep DNA extraction kit from Inqaba Biotech Laboratories South Africa (Pretoria, South Africa). Sample preparation and DNA extraction was carried out following the protocol supplied by the manufacturer.

\subsubsection{Detection and Amplification of $16 \mathrm{~S}$ rRNA by Polymerase Chain Reaction}

The PCR method was performed for detection and amplification of 16S rRNA as described briefly by Frazao et al. [3]. The PCR amplification of the cyanobacteria $16 \mathrm{~S}$ rRNA gene was determined using set of primers $27 \mathrm{~F} / 809 \mathrm{R}$ (Table 2). Thermal cycling conditions were 1 cycle at $95{ }^{\circ} \mathrm{C}$ for $5 \mathrm{~min}, 35$ cycles at $95{ }^{\circ} \mathrm{C}$ for $30 \mathrm{~s}, 55.4{ }^{\circ} \mathrm{C}$ for $30 \mathrm{~s}$ and $72{ }^{\circ} \mathrm{C}$ for $60 \mathrm{~s}$ and 1 cycle at $72{ }^{\circ} \mathrm{C}$ for $10 \mathrm{~min}$. Reactions were carried out in a $50 \mu \mathrm{L}$ reaction volume that consisted of 0.5 pmol of each primer $(10 \mathrm{pM} / \mu \mathrm{L}), 25 \mu \mathrm{L}$ of Dream Taq master mix (Inqaba Biotech), $19 \mu \mathrm{L}$ sterile ultra-pure water and $5 \mu \mathrm{L}$ of DNA sample.

\subsubsection{Toxin Gene Detection}

The presence of cyanotoxins was determined by PCR using primers that were used for detection of genes involved in the production of nodularins (NOD), microcystins (MC) and cylindrospermopsin (CYN) (Table 6). The NOD gene cluster, $n d a$, consists of nine open reading frames (ndaA-I) [79]. The MC gene cluster, $m c y$, comprises 10 genes in two transcribed operons, mcyA-C and $m c y D-J$ [80]. The HEP primer pair was used for detection of genes involved in MC and NOD production. 
These primers are responsible for sequencing the aminotransferase (AMT) domain, which is located on the modules $m c y E$ and $n d a F$ of the MC and NOD synthetase enzyme complexes, respectively $[80,81]$. Primers $m c y A-C$ were used to detect the $m c y A, m c y B$ and $m c y C$ genes $[82,83]$. For detection of CYN production (cyr) genes, the polyketide synthase PKS M4 and M5 primers and the peptide synthetase M13 and M14 primers were used as designed by Schembri et al. [84], who demonstrated a direct link between the presence of the peptide synthetase and polyketide synthase genes and the ability of cyanobacteria to produce CYN.

Table 6. The PCR primers used for amplification of 16S rRNA gene for cyanobacteria identification and for the amplification of genes related to cyanotoxins production. A-Individual annealing temperature, $\mathrm{B}$-Reference annealing temperature, $\mathrm{bp}=$ base pairs.

\begin{tabular}{|c|c|c|c|c|c|c|c|}
\hline Primers & Target Genes & Sequence $\left(5^{\prime}-3^{\prime}\right)$ & $\mathbf{A}$ & B & Size (bp) & Amplified Gene & Ref. \\
\hline $\begin{array}{c}27 \mathrm{~F} \\
809 \mathrm{R}\end{array}$ & - & $\begin{array}{c}\text { AGAGTTTGATCCTGGCTCAG } \\
\text { GCTTCGGCACGGCTCGGGTCGATA }\end{array}$ & $\begin{array}{l}52 \\
64\end{array}$ & 60 & 780 & 16S rRNA & {$[85,86]$} \\
\hline $\begin{array}{l}m c y A-C d \mathrm{~F} \\
m c y A-C d \mathrm{R}\end{array}$ & $m c y A$ & $\begin{array}{l}\text { AAAATTAAAAGCCGTATCAAA } \\
\text { AAAAGTGTTTTATTAGCGGCTCAT }\end{array}$ & $\begin{array}{l}51 \\
43 \\
\end{array}$ & 59 & 297 & $\begin{array}{l}\text { Microcystin } \\
\text { synthetase }\end{array}$ & [83] \\
\hline $\begin{array}{l}\text { HEPF } \\
\text { HEPR }\end{array}$ & mcyE/ndaF & $\begin{array}{l}\text { TTTGGGGTTAACTTTTTTGGGCATAGTC } \\
\text { AATTCTTGAGGCTGTAAATCGGGTTT }\end{array}$ & $\begin{array}{l}57 \\
55\end{array}$ & 52 & 472 & $\begin{array}{l}\text { Microcystin/nodularin } \\
\text { synthetase }\end{array}$ & [81] \\
\hline $\begin{array}{l}\text { PKS M4 } \\
\text { PKS M5 }\end{array}$ & cyr & $\begin{array}{l}\text { GAAGCTCTGGAATCCGGTAA } \\
\text { AATCCTTACGGGATCCGGTGC }\end{array}$ & $\begin{array}{l}52 \\
56\end{array}$ & 55 & 650 & $\begin{array}{l}\text { Cylindrospermopsin } \\
\text { polypeptide synthase }\end{array}$ & [84] \\
\hline $\begin{array}{l}\text { M13 } \\
\text { M14 }\end{array}$ & ps & $\begin{array}{l}\text { GGCAAATTGTGATAGCCACGAGC } \\
\text { GATGGAACATCGCTCACTGGTG }\end{array}$ & $\begin{array}{l}57 \\
57\end{array}$ & 55 & 597 & $\begin{array}{l}\text { Cylindrospermopsin } \\
\text { peptide synthetase }\end{array}$ & [84] \\
\hline
\end{tabular}

The PCR reaction conditions that were used were those described for the amplification of the $16 \mathrm{~S}$ rRNA gene [81]. Concerning the cycling conditions, for $m c y A-C d$ genes, the thermal cycling conditions were 1 cycle at $95^{\circ} \mathrm{C}$ for $2 \mathrm{~min}, 35$ cycles at $95^{\circ} \mathrm{C}$ for $90 \mathrm{~s}, 56^{\circ} \mathrm{C}$ for $30 \mathrm{~s}$ and $72{ }^{\circ} \mathrm{C}$ for $50 \mathrm{~s}$ and $1 \mathrm{cycle}$ at $72{ }^{\circ} \mathrm{C}$ for $7 \mathrm{~min}$. For HEP and $\mathrm{CYN}$ as genes, the thermal cycling conditions were as those for the amplification of the $16 \mathrm{~S}$ rRNA with an exception for HEP gene annealing temperature of $58.15^{\circ} \mathrm{C}$ for 30 s. Positive control was used.

\section{Electrophoresis}

PCR products were electrophoresed in $0.8 \%$ agarose gel by adding prepared $1.2 \mathrm{~g}$ of agarose powder into $150 \mathrm{~mL} 1 \mathrm{X}$ TAE buffer (48.4 $\mathrm{g}$ Tris, $11.4 \mathrm{~mL}$ Glacial acetic acid, $3.7 \mathrm{~g}$ EDTA disodium salt topped up to $1000 \mathrm{~mL}$ with deionized water). The mixture was heated until there was complete dissolution. Exactly $10 \mu \mathrm{L}$ of ethidium bromide was added and mixed thoroughly. The mixture was transferred to the gel-casting tray with the comb already in position and allowed to solidify. The solidified gel was transferred to the running trays. The gel in the tray was covered with 1X TAE buffer. In the first well $3 \mu \mathrm{L} 100 \mathrm{bp}$ of the molecular weight marker was loaded and the samples were loaded from the second well onwards. The gel was run at $100 \mathrm{~V}$ and $250 \mathrm{~mA}$ for $60 \mathrm{~min}$. The gel was viewed using the Gel doc (Biorad, Hercules, CA, USA) and the picture was taken.

\subsubsection{PCR Purification and Sequencing}

PCR products were purified using the GeneJet Gel Extraction Kit Thermo Scientific (Pretoria, South Africa) under room temperature as per the protocol provided by the kit manufacturer. The purified DNA was stored at $-20{ }^{\circ} \mathrm{C}$. PCR products were sent for sequencing at Inqaba biotech laboratory (Pretoria, South Africa). Sequences were analyzed using the BLAST system (http://www.ncbi.nlm.nih.gov/BLAST/).

\section{Primers}

Primers used for PCR amplification were synthesized at Inqaba Biotech (Pretoria, South Africa). Details of primer sequences, their specific targets and amplicon sizes are summarized (Table 6) below. 


\subsubsection{Phylogenetic Relationship}

Additional sequences were downloaded in FASTA format from GenBank through NCBI and combined with assembled sequences. The evolutionary history was inferred using the Neighbor-Joining method [87]. The bootstrap consensus tree inferred from 1000 replicates [88] is taken to represent the evolutionary history of the taxa analyzed [88]. Branches corresponding to partitions reproduced in fewer than $50 \%$ bootstrap replicates are collapsed. The percentage of replicate trees in which the associated taxa clustered together in the bootstrap test (1000 replicates) is shown next to the branches [88]. The evolutionary distances were computed using the Kimura 2-parameter method [35] and are in the units of the number of base substitutions per site. The analysis involved 25 nucleotide sequences. Codon positions included were $1 s t+2 n d+3 r d+$ Noncoding. All positions containing gaps and missing data were eliminated. There were a total of 640 positions in the final dataset. Evolutionary analyses were conducted in MEGA7 [34].

\subsubsection{Divergence Matrix}

PCR products for the 16S rRNA gene, identified on agarose gels, were selected for subsequent identification by sequencing (Inqaba Biotech, Pretoria, South Africa). The obtained sequenced data were used to conduct homology searches on GenBank using BLAST (http:/ / blast.ncbi.nlm.nih.gov / blast.cgi) [89], and for further bioinformatic analyses to perform divergence matrix using BioEdit v7.0.9 [33]). Sequences were exported to and analyzed with the MEGA 7 package [34].

Author Contributions: M.M., P.J.O., J.R.G. conceived and designed the study; M.M., J.R.G. collected samples and performed the study; M.M., A.S., S.M., J.R.G. analyzed the data; M.M., P.J.O., J.R.G., A.S., S.M. wrote the paper.

Acknowledgments: We acknowledge financial support from National Research Foundation (NRF) and University of Venda Research and Publication Committee (RPC) and Eskom Tertiary Support Program (TESP) for the research study.

Conflicts of Interest: The authors declare no conflict of interest.

\section{References}

1. Christiansen, G.; Molitor, C.; Philmus, B.; Kurmayer, R. Nontoxic strains of cyanobacteria are the result of major gene deletion events induced by a transposable element. Mol. Biol. Evol. 2008, 25, 1695-1704. [CrossRef] [PubMed]

2. Janse, I.; Kardinaal, W.E.A.; Meima, M.; Fastner, J.; Visser, P.M.; Zwart, G. Toxic and nontoxic Microcystis colonies in natural populations can be differentiated on the basis of rRNA gene internal transcribed spacer diversity. Appl. Environ. Microbiol. 2004, 70, 3979-3987. [CrossRef] [PubMed]

3. Frazao, B.; Martins, R.; Vasconcelos, V. Are Known Cyanotoxins Involved in the Toxicity of Picoplanktonic and Filamentous North Atlantic Marine Cyanobacteria? Mar. Drugs 2010, 8, 1908-1919. [CrossRef] [PubMed]

4. Pearson, L.A.; Dittmann, E.; Mazmouz, R.; Ongley, S.E.; D'Agostino, P.M.; Neilan, B.A. The genetics, biosynthesis and regulation of toxic specialized metabolites of cyanobacteria. Harmful Algae 2016, 54, 98-111. [CrossRef] [PubMed]

5. Sinha, R.; Pearson, L.A.; Davis, T.W.; Muenchhoff, J.; Pratama, R.; Jex, A.; Neilan, B.A. Comparative genomics of Cylindrospermopsis raciborskii strains with differential toxicities. BMC Genom. 2014, 15, 83. [CrossRef] [PubMed]

6. Gumbo, R.J.; Ross, G.; Cloete, E.T. Biological control of Microcystis dominated harmful algal blooms. Afr. J. Biotechnol. 2008, 7, 4765-4773.

7. Paerl, H.W.; Fulton, R.S.; Moisander, P.H.; Dyble, J. Harmful freshwater algal blooms with an emphasis on cyanobacteria. Sci. World 2001, 1, 76-113. [CrossRef] [PubMed]

8. Boyer, G.L. Toxic Cyanobacteria in the Great Lakes: More than just the Western Basin of Lake Erie. GLRC Great Lakes Res. Rev. 2006, 7, 2-7.

9. O'Neil, J.M.; Davis, T.W.; Burford, M.A.; Gobler, C.J. The rise of harmful cyanobacteria blooms: The potential roles of eutrophication and climate change. Harmful Algae 2012, 14, 313-334. [CrossRef] 
10. Vitousek, P.M.J.; Aber, R.W.; Howarth, G.E.; Likens, P.A.; Matson, D.W.; Schindler, W.H.; Tilman, G.D. Human alteration of the global nitrogen cycle: Causes and consequences. Issues Ecol. 1997, 1, 1-17.

11. Scheffer, M. The story of some shallow lakes. In Ecology of Shallow Lakes; Springer: Dordrecht, The Netherlands, 2004; pp. 1-19.

12. Reynolds, C.S. Ecology of Phytoplankton; Cambridge University Press: Cambridge, UK, 2006; 550p.

13. Smith, V.H. Low nitrogen to phosphorus ratios favor dominance by blue-green algae in lake Phytoplankton. Science 1983, 221, 669-671. [CrossRef] [PubMed]

14. Hyenstrand, P. Factors Influencing the Success of Pelagic Cyanobacteria; Uppsala University: Uppsala, Sweden, 1999.

15. Berman, T. The role of DON and the effect of N: P ratios on occurrence of cyanobacterial blooms: Implications from the outgrowth of Aphanizomenon in Lake Kinneret. Limnol. Oceanogr. 2001, 46, 443-447. [CrossRef]

16. Downing, J.A.; Watson, S.B.; McCauley, E. Predicting cyanobacteria dominance in lakes. Can. J. Fish. Aquat. Sci. 2001, 58, 1905-1908. [CrossRef]

17. Von Ruckert, G.; Giani, A. Effect of nitrate and ammonium on the growth and protein concentration of Microcystis viridis Lemmermann (Cyanobacteria). Rev. Brasiliera Bot. 2004, 27, 325-331.

18. McCarthy, M.J.; Gardner, W.S.; Lavrentyev, P.J.; Moats, K.M.; Joehem, F.J.; Klarer, D.M. Effects of hydrological flow regime on sediment-water interface and water column nitrogen dynamics in a great lakes coastal wetland (Old Woman Creek, Lake Erie). J. Great Lakes Res. 2007, 33, 219-231. [CrossRef]

19. Andersen, K.; Shanmugam, K. Energetics of biological nitrogen fixation: Determination of the ratio of formation of $\mathrm{H} 2$ to $\mathrm{NH} 4+$ catalyzed by nitrogenase of Klebsiella pneumoniae in vivo. J. Gen. Microbiol. 1977, 103, 107-122. [CrossRef] [PubMed]

20. Visser, P.M. Growth and Vertical Movement of the Cyanobacterium Microcystis in Stable and Artificially Mixed Water Columns. Ph.D. Thesis, University of Amsterdam, Amsterdam, The Netherland, 1995.

21. Thiel, T.; Pratte, B. Effect on heterocyst differentiation of nitrogen fixation in vegetative cells of the cyanobacterium Anabaena variabilis ATCC 29413. J. Bacteriol. 2001, 183, 280-286. [CrossRef] [PubMed]

22. Chan, F.; Pace, M.L.; Howarth, R.W.; Marino, R.M. Bloom formation in heterocystic nitrogen-fixing cyanobacteria: The dependence on colony size and zooplankton grazing. Limnol. Oceanogr. 2004, 49, 2171-2178. [CrossRef]

23. Mbukwa, E.; Msagati, T.A.; Mamba, B.B.; Boussiba, S.; Wepener, V.; Leu, S.; Kaye, Y. Toxic Microcystis novacekii T20-3 from Phakalane Ponds, Botswana: PCR Amplifications of Microcystin Synthetase (mcy) Genes, Extraction and LC-ESI-MS Identification of Microcystins. J. Environ. Anal. Toxicol. 2015. [CrossRef]

24. Mbukwa, E.A.; Boussiba, S.; Wepener, V.; Leu, S.; Kaye, Y.; Msagati, T.A.; Mamba, B.B. PCR amplification and DNA sequence of $m c y A$ gene: The distribution profile of a toxigenic Microcystis aeruginosa in the Hartbeespoort Dam, South Africa. J. Water Health 2013, 11, 563-572. [CrossRef] [PubMed]

25. Pedro, O.; Rundberget, T.; Lie, E.; Correia, D.; Skaare, J.U.; Berdal, K.G.; Neves, L.; Sandvik, M. Occurrence of microcystins in freshwater bodies in Southern Mozambique. J. Res. Environ. Sci. Toxicol. 2012, 1, 58-65.

26. Vézie, C.; Rapala, J.; Vaitomaa, J.; Seitsonen, J.; Sivonen, K. Effect of nitrogen and phosphorus on growth of toxic and nontoxic Microcystis strains and on intracellular microcystin concentrations. Microb. Ecol. 2002, 43, 443-454. [CrossRef] [PubMed]

27. Beversdorf, L.J.; Miller, T.R.; McMahon, K.D. The role of nitrogen fixation in cyanobacterial bloom toxicity in a temperate, eutrophic lake. PLoS ONE 2013, 8, e56103. [CrossRef] [PubMed]

28. Celeste, C.M.M.; Lorena, R.; Oswaldo, A.J.; Sandro, G.; Daniela, S.; Dario, A.; Leda, G. Mathematical modeling of Microcystis aeruginosa growth and [D-Leu1] microcystin-LR production in culture media at different temperatures. Harmful Algae 2017, 67, 13-25. [CrossRef] [PubMed]

29. Van der Westhuizen, A.J.; Eloff, J.N. Effect of temperature and light on the toxicity and growth of the blue-green alga Microcystis aeruginosa (UV-006). Planta 1985, 163, 55-59. [CrossRef] [PubMed]

30. Geada, P.; Pereira, R.N.; Vasconcelos, V.; Vicente, A.A.; Fernandes, B.D. Assessment of synergistic interactions between environmental factors on Microcystis aeruginosa growth and microcystin production. Algal Res. 2017, 27, 235-243. [CrossRef]

31. Ndlela, L.L.; Oberholster, P.J.; Van Wyk, J.H.; Cheng, P.H. An overview of cyanobacterial bloom occurrences and research in Africa over the last decade. Harmful Algae 2016, 60, 11-26. [CrossRef] [PubMed]

32. Staden, R.; Judge, D.P.; Bonfield, J.K. Analysing sequences using the Staden package and EMBOSS. In Introduction to Bioinformatics. A Theoretical and Practical Approach; Human Press Inc.: Totawa, NJ, USA, 2003. 
33. Hall, T.A. BioEdit: A user-friendly biological sequence alignment editor and analysis program for Windows 95/98/NT. Nucleic Acids Symp. Ser. 1990, 41, 95-98.

34. Kumar, S.; Stecher, G.; Tamura, K. MEGA7: Molecular Evolutionary Genetics Analysis version 7.0 for bigger datasets. Mol. Biol. Evol. 2016, 33, 1870-1874. [CrossRef] [PubMed]

35. Kimura, M. A simple method for estimating evolutionary rate of base substitutions through comparative studies of nucleotide sequences. J. Mol. Evol. 1980, 16, 111-120. [CrossRef] [PubMed]

36. Oberholster, P.J.; Botha, A.M.; Myburgh, J.G. Linking climate change and progressive eutrophication to incidents of clustered animal mortalities in different geographical regions of South Africa. Afr. J. Biotechnol. 2009, 8, 5825-5832.

37. Peperzak, L. Climate change and harmful algal bllom in the North Sea. Acta Oecol. 2003, 24, 139-144. [CrossRef]

38. Rantala, A.; Rajaniemi-Wacklin, P.; Lyra, C.; Lepisto, L.; Rintala, J.; Mankiewiez-Boczek, J.; Sivonen, K. Detection of microcystin-producing cyanobacteria in Finnish Lakes with genus-specific microcystin synthetase Gene E (mcyE) PCR and associations with environmental factors. Appl. Environ. Microbiol. 2006, 72, 6101-6110. [CrossRef] [PubMed]

39. Jahnichen, S.; Petzoldt, T.; Benndorf, J. Evidence for control of microcystin dynamics in BautzenReservoir (Germany) by cyanobacterial population growth rates and dissolved inorganic carbon. Arch. Hydrobiol. 2001, 150, 177-196. [CrossRef]

40. Bartram, J.; Chorus, I.; Carmichael, W.W.; Jones, G.; Skulberg, O.M. Toxic Cyanobacteria in Water. A Guide to Their Public Health Consequences, Monitoring and Management; Chorus, I., Bartram, J., Eds.; World Health Organization: Geneva, Switzerland, 1999; pp. 1-14.

41. Xu, H.; Paerl, H.W.; Qin, B.; Zhu, G.; Gaoa, G. Nitrogen and phosphorus inputs control phytoplankton growth in eutrophic Lake Taihu, China. Limnol. Oceanogr. 2010, 55, 420-432. [CrossRef]

42. Edokpayi, J.N.; Odiyo, J.O.; Popoola, E.O.; Msagati, T.A. Evaluation of Microbiological and Physicochemical Parameters of Alternative Source of Drinking Water: A Case Study of Nzhelele River, South Africa. Open Microbiol. J. 2018, 12, 18-27. [CrossRef] [PubMed]

43. Burne, C. Macro-Nutrient and Hydrological Trends in Some Streams of the Waterberg, Limpopo: Investigating the Effects of Land-Use Change on Catchment Water Quality. Master's Dissertation, University of Witwatersrand, Johannesburg, South Africa, 2016.

44. Correll, D.L. Phosphorus: A rate limiting nutrient in surface waters. Poultry Sci. 1999, 78, 674-682. [CrossRef] [PubMed]

45. Oberholster, P.J.; Dabrowski, J.; Botha, A.M. Using modified multiple phosphorus sensitivity indices for mitigation and management of phosphorus loads on a catchment level. Fundam. Appl. Limnol. Arch. Hydrobiol. 2013, 182, 1-16. [CrossRef]

46. Mosimanegape, K. Integration of Physicochemical Assessment of Water Quality with Remote Sensing Techniques for the Dikgathong Damin Botswana. Master's Dissertation, University of Zimbabwe, Harare, Zimbabwe, 2016.

47. Matthews, M.W. Eutrophication and cyanobacterial blooms in South African inland waters: 10 years of MERIS observations. Remote Sens. Environ. 2014, 155, 161-177. [CrossRef]

48. Swanepoel, A.; Du Preez, H.H.; Cloete, N. The occurrence and removal of algae (including cyanobacteria) and their related organic compounds from source water in Vaalkop Dam with conventional and advanced drinking water treatment processes. Water SA 2017, 43, 67-80. [CrossRef]

49. Seanego, K.G.; Moyo, N.A.G. The effect of sewage effluent on the physico-chemical and biological characteristics of the Sand River, Limpopo, South Africa. Phys. Chem. Earth Parts A/B/C 2013, 66, 75-82. [CrossRef]

50. Musa, R.; Greenfield, R. Nutrient loads on an important watercourse. Pre-and Post-Acid spill. In Proceedings of the 7th International Toxicology Symposium, Johannesburg, South Africa, 31 August 2015; p. 89.

51. Basima, L.B. An Assessment of Plankton Diversity as a Water Quality Indicator in Small Man-m Ade Reservoirs in the Mzingwane Catchment, Limpopo Basin, Zimbabwe. Master's Dissertation, University of Zimbabwe, Harare, Zimbabwe, 2005.

52. Mupfiga, E.T.; Munkwakwata, R.; Mudereri, B.; Nyatondo, U.N. Assessment of sedimentation in Tuli Makwe Dam using remotely sensed data. J. Soil Sci. Environ. Manag. 2016, 7, 230-238. 
53. Mavhunga, M. The Presence of Cyanobacteria \& Diatoms in Limpopo River Sediment Profile: Implications for Human Health. Unpublished Hons mini Thesis, University of Venda, Johannesburg, South Africa, 2015.

54. Oberholster, P.J.; Jappie, S.; Cheng, P.H.; Botha, A.M.; Matthews, M.W. First report of an Anabaena Bory strain containing microcystin-LR in a freshwater body in Africa. Afr. J. Aquat. Sci. 2015, 40, 21-36. [CrossRef]

55. Kim, Y.J.; Baek, J.S.; Youn, S.J.; Kim, H.N.; Lee, B.C.; Kim, G.; Park, S.; You, K.A.; Lee, J.K. Cyanobacteria Community and Growth Potential Test in Sediment of Lake Paldang. J. Korean Soc. Water Environ. 2016, 32, 261-270. [CrossRef]

56. Dzebu, W. Statement in Relation to Water Supply Challenges in Musina, 14 March 2017. Available online: www.musina.gov.za/index.php/public-notices?download=1028...in...to...musina (accessed on 26 March 2014).

57. Botha, A.M.; Oberholster, P.J. PCR-Based Markers for Detection and Identification of Toxic Cyanobacteria; WRC Report No. K5/1502/01/07; Water Research Commission: Pretoria, South Africa, 2007; p. 70.

58. Su, Y.; You, X.; Lin, H.; Zhuang, H.; Weng, Y.; Zhang, D. Recruitment of cyanobacteria from the sediments in the eutrophic Shanzi Reservoir. Environ. Technol. 2016, 37, 641-651. [CrossRef] [PubMed]

59. Maldener, I.; Summers, M.L.; Sukenik, A. Cellular differentiation in filamentous cyanobacteria. In The Cell Biology of Cyanobacteria; Flores, E., Herrero, A., Eds.; Caister Academic Press: Norwich, UK, 2014; pp. $263-291$.

60. Perez, R.; Forchhammer, K.; Salerno, G.; Maldener, I. Clear differences in metabolic and morphological adaptations of akinetes of two Nostocales living in different habitats. Microbiology 2016, 162, $214-223$. [CrossRef] [PubMed]

61. Adam, D.G.; Duggan, P.S. Heterocyst and akinete differentiation in cyanobacteria. New Phytol. 1999, 144, 3-33. [CrossRef]

62. Scherer, P.I.; Raeder, U.; Geist, J.; Zwirglmaier, K. Influence of temperature, mixing, and addition of microcystin-LR on microcystin gene expression in Microcystis aeruginosa. Microbiol. Open 2017, 6. [CrossRef] [PubMed]

63. Mikalsen, B.; Boison, G.; Skulberg, O.M.; Fastner, J.; Davies, W.; Gabrielsen, T.M.; Rudi, K.; Jakobsen, K.S. Natural variation in the microcystin synthetase operon $m c y A B C$ and impact on microcystin production in Microcystis strains. J. Bacteriol. 2003, 185, 2774-2785. [CrossRef] [PubMed]

64. Davis, T.W.; Berry, D.L.; Boyer, G.L.; Gobler, C.J. The effects of temperature and nutrients on the growth and dynamics of toxic and non-toxic strains of Microcystis during cyanobacteria blooms. Harmful Algae 2009, 8, 715-725. [CrossRef]

65. Yamamoto, Y. Effect of temperature on recruitment of cyanobacteria from the sediment and bloom formation in a shallow pond. Plankton Benthos Res. 2009, 4, 95-103. [CrossRef]

66. Oberholster, P.J.; Botha, A.-M.; Cloete, T.E. Use of molecular markers as indicators for winter zooplankton grazing on toxic benthic cyanobacteria colonies in an urban Colorado lake. Harmful Algae 2006, 5, 705-716. [CrossRef]

67. Mosase, E.; Ahiablame, L. Rainfall and Temperature in the Limpopo River Basin, Southern Africa: Means, Variations, and Trends from 1979 to 2013. Water 2018, 10, 364. [CrossRef]

68. Hoeger, S.J.; Dietrick, D.R.; Hitzfeld, B.C. Effect of ozonation on the removal of cyanobacteria toxins during drinking water treatment. Environ. Health Perspect. 2002, 110, 1127-1132. [CrossRef] [PubMed]

69. Brittain, S.M.; Wang, J.; Babcock-Jackson, L.; Carmichael, W.W.; Rinehart, K.L.; Culver, D.A. Isolation and characterization of microcystins, cyclic heptapeptide hepatotoxins from Lake Erie strain of Microcystis aeruginosa. J. Great Lakes Res. 2000, 26, 241-249. [CrossRef]

70. Andersson, J.A.; de Garine-Wichatitsky, M.; Cumming, D.H.; Dzingirai, V.; Giller, K.E. People at wildlife frontiers in Southern Africa. In Transfrontier Conservation Area: People Living on the Edge; Routledge: Abingdon-on-Thames, UK, 2013; pp. 1-11.

71. Oberholster, P.J.; Myburgh, J.G.; Govender, D.; Bengis, R.; Botha, A.M. Identification of toxigenic Microcystis strains after incidents of wild animal mortalities in the Kruger National Park, South Africa. Ecotoxicol. Environ. Saf. 2009, 72, 1177-1182. [CrossRef] [PubMed]

72. McCollough, B. Toxic Algae and Other Marine Biota: Detection, Mitigation, Prevention and Effects on the Food Industry. Master's Dissertation, Kansas State University, Manhattan, KS, USA, 2016.

73. Zhu, T.; Ringler, C. Climate change impacts on water availability and use in the Limpopo River Basin. Water 2012, 4, 63-84. [CrossRef] 
74. Department of Water Affairs. Joint Water Quality Baseline Report for Limpopo Basin between Botswana and South Africa; Department of Water Affairs: Pretoria, South Africa, 2011.

75. Islam, M.S.; Ahmed, M.K.; Raknuzzaman, M.; Habibullah-Al-Mamun, M.; Islam, M.K. Heavy metal pollution in surface water and sediment: A preliminary assessment of an urban river in a developing country. Ecol. Indic. 2015, 48, 282-291. [CrossRef]

76. APHA; AWWA; WPCF. Standard Methods for Examination of Water and Wastewater, 20th ed.; American Publishing Health Association: Washington, DC, USA, 1998.

77. Gumbo, J.R.; Ross, G.; Cloete, T.E. The Isolation and identification of Predatory Bacteria from a Microcystis algal Bloom. Afr. J. Biotechnol. 2010, 9, 663-671.

78. Van Vuuren, S.J.; Taylor, J.; Gerber, A. A Guide for the Identification of Microscopic Algae in South Africa Freshwaters; Department of Water Affairs and Forestry, North-West University: Potchefstroom, South Africa, 2006.

79. Moffitt, M.C.; Neilan, B.A. Characterization of the nodularin synthetase gene cluster and proposed theory of the evolution of cyanobacterial hepatotoxins. Appl. Environ. Microbiol. 2004, 70, 6353-6362. [CrossRef] [PubMed]

80. Pearson, L.A.; Neilan, B.A. The molecular genetics of cyanobacterial toxicity as a basis for monitoring water quality and public health risk. Curr. Opin. Biotechnol. 2008, 19, 281-288. [CrossRef] [PubMed]

81. Jungblut, A.D.; Neilan, B.A. Molecular identification and evolution of the cyclic peptide hepatotoxins, microcystin and nodularin, synthetase genes in three orders of cyanobacteria. Arch. Microbiol. 2006, 185, 107-114. [CrossRef] [PubMed]

82. Fergusson, K.M.; Saint, C.P. Multiplex PCR assay for Cylindrospermopsis raciborskii and cylindrospermopsin-producing cyanobacteria. Environ. Toxicol. 2003, 18, 120-125. [CrossRef] [PubMed]

83. Hisbergues, M.; Christiansen, G.; Rouhiainen, L.; Sivonen, K.; Borner, T. PCR-based identification of microcystin-producing genotypes of different cyanobacterial genera. Arch. Microbiol. 2003, 180, 402-410. [CrossRef] [PubMed]

84. Schembri, M.A.; Neilan, B.A.; Saint, C.P. Identification of genes implicated in toxin production in the cyanobacterium Cylindrospermopsis raciborskii. Environ. Toxicol. 2001, 16, 413-421. [CrossRef] [PubMed]

85. Neilan, B.A.; Jacobs, D.; Del Dot, T.; Blackall, L.L.; Hawkins, P.R.; Cox, P.T.; Goodman, A.E. rRNA sequences and evolutionary relationships among toxic and nontoxic cyanobacteria of the genus Microcystis. Int. J. Syst. Bacteriol. 1997, 47, 693-697. [CrossRef] [PubMed]

86. Jungblut, A.D.; Hawes, I.; Mountfort, D.; Hitzfeld, B.; Dietrich, D.R.; Burns, B.P.; Neilan, B.A. Diversity within cyanobacterial mat communities in variable salinity meltwater ponds of McMurdo Ice Shelf, Antarctica. Environ. Microbiol. 2005, 7, 519-529. [CrossRef] [PubMed]

87. Saitou, N.; Nei, M. The neighbor-joining method: A new method for reconstructing phylogenetic trees. Mol. Biol. Evol. 1987, 4, 406-425. [PubMed]

88. Felsenstein, J. Confidence limits on phylogenies: An approach using the bootstrap. Evolution 1985, 39, 783-791. [CrossRef] [PubMed]

89. Altschul, S.F.; Gish, W.; Miller, W.; Myers, E.W.; Lipman, D.J. “Gapped Blast and PSI-BLAST” A generation of protein database search programs. Nucleic Acids Res. 1997, 25, 3389-3402. [CrossRef] [PubMed]

(C) 2018 by the authors. Licensee MDPI, Basel, Switzerland. This article is an open access article distributed under the terms and conditions of the Creative Commons Attribution (CC BY) license (http:/ / creativecommons.org/licenses/by/4.0/). 